\title{
Informal urban green space - A trilingual systematic review of its role for biodiversity and trends in the literature
}

Authors' manuscript, accepted at Urban Forestry \& Urban Greening July 11, 2015.

Version of record: http://dx.doi.org/10.1016/j.landurbplan.2015.07.003

Citation: Rupprecht, C.D.D., Byrne, J.A., Garden, J.G., Hero, J.-M., (in press). Informal urban green space: A trilingual systematic review of its role for biodiversity and trends in the literature. Urban Forestry \& Urban Greening. doi:10.1016/j.ufug.2015.08.009

Christoph D. D. RUPPRECHT ${ }^{1,2}$ (Corresponding author)

Email: $\quad$ christoph.rupprecht@griffithuni.edu.au

Address: $\quad$ Room 3.16, Building G31, Griffith University QLD 4222, Australia

Phone: $\quad+6175552-9340$

Jason A. BYRNE ${ }^{1,2}$ (jason.byrne@griffith.edu.au)

Jenni G. GARDEN $\mathbf{N}^{1,3}$ (j.garden@griffith.edu.au)

Jean-Marc HERO ${ }^{1,2}$ (m.hero@griffith.edu.au)

\section{Affiliations}

1. Environmental Futures Research Institute, Griffith University, Nathan QLD 4111, Australia

2. Griffith School of Environment, Griffith University, Gold Coast QLD 4222, Australia

3. Seed Consulting Services, 106 Gilles Street, Adelaide 5000, South Australia

\begin{abstract}
Urban greenspaces harbor considerable biodiversity. Such areas include spontaneously vegetated spaces such as such as brownfields, street or railway verges and vacant lots. While these spaces may contribute to urban conservation, their informal and liminal nature poses a challenge for reviewing what we know about their value for biodiversity. The relevant literature lacks a common terminology. This paper applied a formal definition and typology of informal urban greenspace (IGS) to identify and systematically review a total of 174 peer-reviewed papers in English (152), German (14) and Japanese (8). We identified three main topics: value for conservation (94 papers), factors influencing diversity (80), and non-indigenous species (37). Additionally, we analyzed this literature for temporal trends, spatial patterns, studied IGS types, taxa, climate zones, human impact types, and key authors. Results show IGS plays an important role for biodiversity. Management practices were identified as the most common and negative impact on diversity, while vegetation, site age, distance to city center, and habitat diversity were positive-influence factors. The number and impact of non-indigenous species varied widely. The analysis of literature patterns reveals: an increase in publications over the last 15 years and a strong geographic bias in publications, as well as towards temperate and humid climate zones. Studies of gap, powerline and microsite IGS were scarce, as were studies of mammals and reptiles. Results suggest different maintenance regimes for IGS may improve its contribution to urban conservation. We therefore propose adapting management to the local context. (243/250 words)
\end{abstract}

Keywords: urban ecology; conservation; wasteland; spontaneous vegetation; cities, liminal

\section{Introduction}

Some of the biggest conservation challenges, and most permanent ecological changes occur in cities and towns (Goddard et al., 2010; Kowarik, 2011). Much of the research on urban forestry and urban 
greening is dedicated to two types of spaces: (1) naturally vegetated spaces (e.g. remnants of the pre-development vegetation), and (2) highly managed spaces with planted vegetation (e.g. formal parks and gardens). Yet many scholars have emphasized the potential of spontaneously vegetated spaces (e.g. brownfields, street or railway verges etc.) for urban conservation (Del Tredici, 2010a; Kowarik, 2011; Kühn, 2006). For example, recent reviews concluded urban wasteland can contribute to biodiversity conservation in urban regions (Bonthoux et al., 2014; Gardiner et al., 2013), and quantitative research suggests such spaces cover around five percent of surveyed cities (Rupprecht and Byrne, 2014a). However, knowledge of this topic is still quite limited. Most of what we know is derived from English language literature. In contrast to research on parks and conservation areas, research on informal green spaces also faces a conceptual challenge that complicates identifying relevant papers - namely the lack of an agreed approach about how to define these spaces.

In absence of a formal definition, researchers from urban geography and other fields have explored the characteristics of informal green spaces. They argue such spaces are 'liminal' (Rupprecht and Byrne, 2014b), and hard to identify and analyze because they form an 'ambivalent landscape' (Jorgensen and Tylecote, 2007) where land tenure, conservation, maintenance regimes, use, regulation, and legitimacy are fraught with uncertainty (McLain et al., 2014). Liminality is a term emerging from the social sciences (Rupprecht and Byrne, 2014a). It refers to a condition of becoming, a transitional state of 'in-between-ness' or hybridity - distinguished by temporal and spatial flux - and not easily categorized (Sweeney, 2009). As Pritchard and Morgan (2006, 764-65) note, liminal spaces: 'are borderlands between the mundane and the extraordinary...betwixt places...[that are] mutable'. Head and Muir $(2006,506)$ assert that in liminal spaces can be found 'complex entanglements of humans and nature...[where] ...nature and culture are reinforced, maintained or ruptured' and 'belonging is highly contingent'. Instone and Sweeney (2014) astutely observe that for liminal ecologies, the culture/nature boundary is disrupted and divisions between public/private and controlled/neglected are blurred. In sum, liminal spaces are 'interfaces' or intersections of cooperation and competition, separation and reintegration, characterized by informality and emergence (Imai, 2013).

The liminality of IGS may explain why researchers have referred to it using a variety of different names, such as 'urban wilderness', 'urban wildscapes', 'ambivalent landscapes' or 'urban wasteland' (Rupprecht and Byrne, 2014b). Without clearly specifying the object of study, researchers risk overlooking important details about the attributes of these spaces and may remain ignorant about a body of relevant and important previous research. Moreover, without definitional certainty - that we are studying the same object, efforts to compare between different research findings and to build knowledge are severely impeded. To address this issue, Rupprecht and Byrne advanced a definition and typology of 'informal urban green space' (IGS) in a field survey of IGS quantity (2014a) and provided a review of IGS' role and value for urban residents (2014b). But there is still a lack of knowledge about the biodiversity value of these spaces. This paper reviews the scholarly literature on IGS and urban biodiversity, using the analytical framework provided by Rupprecht and Byrne (2014a), offering researchers, planners, and stakeholders an integrated understanding and synthesis of research findings.

Specifically, the review aims to address two sets of questions. The first set targets the role of IGS for urban biodiversity: (1.a) how is IGS valuable to urban biodiversity conservation; (1.b) what factors influence IGS biodiversity; and (1.c) how is IGS used by indigenous and non-indigenous species? The second set of questions targets patterns and trends in the scholarly knowledge of IGS biodiversity: (2.a) how has the number of relevant publications changed over time; (2.b) what is the spatial and linguistic structure of the literature; (2.c) which IGS types have been studied most; (2.d) 
which species groups have been studied most; (2.e) what forms of human impact are most common; (2.f) what are the most studied climate zones; and (2.g) who are the key authors? These questions assist in identifying knowledge gaps and identifying directions for future research. To answer these questions, this paper provides a concise, tri-lingual review of 174 peer-reviewed research papers on the biodiversity of IGS. Findings have important policy implications for biodiversity conservation in urban areas.

\section{Methods}

We used a systematic review approach (Pickering and Byrne, 2013) that differs from a classic metaanalysis. The systematic review has recently emerged as a useful tool for scholarly literature analysis (Byrne and Portanger, 2014; Guitart et al., 2012; Roy et al., 2012). Such reviews do not analyze published data; rather they identify geographic, theoretical and methodological gaps by analyzing trends in the literature. Similar to a recent systematic review of the role of IGS for urban residents (Rupprecht and Byrne, 2014b), this review included German, Japanese and English papers to extend the scope of the review. These languages were chosen based on the multi-lingual proficiency of the review's first author. Preliminary searches revealed IGS-related research papers published in other languages, such as Spanish (Lopez-Moreno et al., 2003) and Russian (Tikhonova et al., 2002), and we recognize that we have not been able to address papers published in many other languages (e.g. Mandarin, French, Portuguese etc.) - a point we return to in the discussion.

For this review, we systematically searched five major databases (Web of Knowledge, Scopus, Google Scholar, CiNii and J-STAGE) using Boolean functions to combine search terms, for example "urban AND species AND [all biodiversity terms with OR functions] AND [IGSvariable]" (for full list of search terms in all three languages see Appendix A). Database searches were performed in early 2011 for the full time frames available, and updated in early 2013 and late 2014 with a repeated search in Web of Knowledge, Scopus, Google Scholar, and J-STAGE for papers published since the first search. We did not seek to impose a time limit on the search (e.g. 20 years) but it should be noted that not all older papers may be full-text searchable, a limitation that may cause them to be underrepresented. We selected a number of research papers specifically targeting IGS to look in their reference sections for additional potentially relevant publications not returned in the database searches.

To be included for analysis, publications had to meet three inclusion criteria: (1) the studied area comprised or included at least one type of IGS following Rupprecht and Byrne's typology (2014a, 2014b)(Table 1, Fig. 1); (2) the study reported sufficient details to identify a space as IGS (e.g. in urban area, management arrangements, official park designation, site history); (3) the data reported for an IGS was sufficient to include the study in the analysis of literature trends (e.g. target species group). All feasible effort was made to clarify whether a study area fulfilled the requirements to be included; aside from a close examination of all information provided in the publication, study areas were (if possible) also located in Google Earth. Aerial photography and photographic material in Google Earth was sighted to examine whether site conditions and site context in the urban matrix complied with the three selection criteria above (a form of "ground-truthing"). 

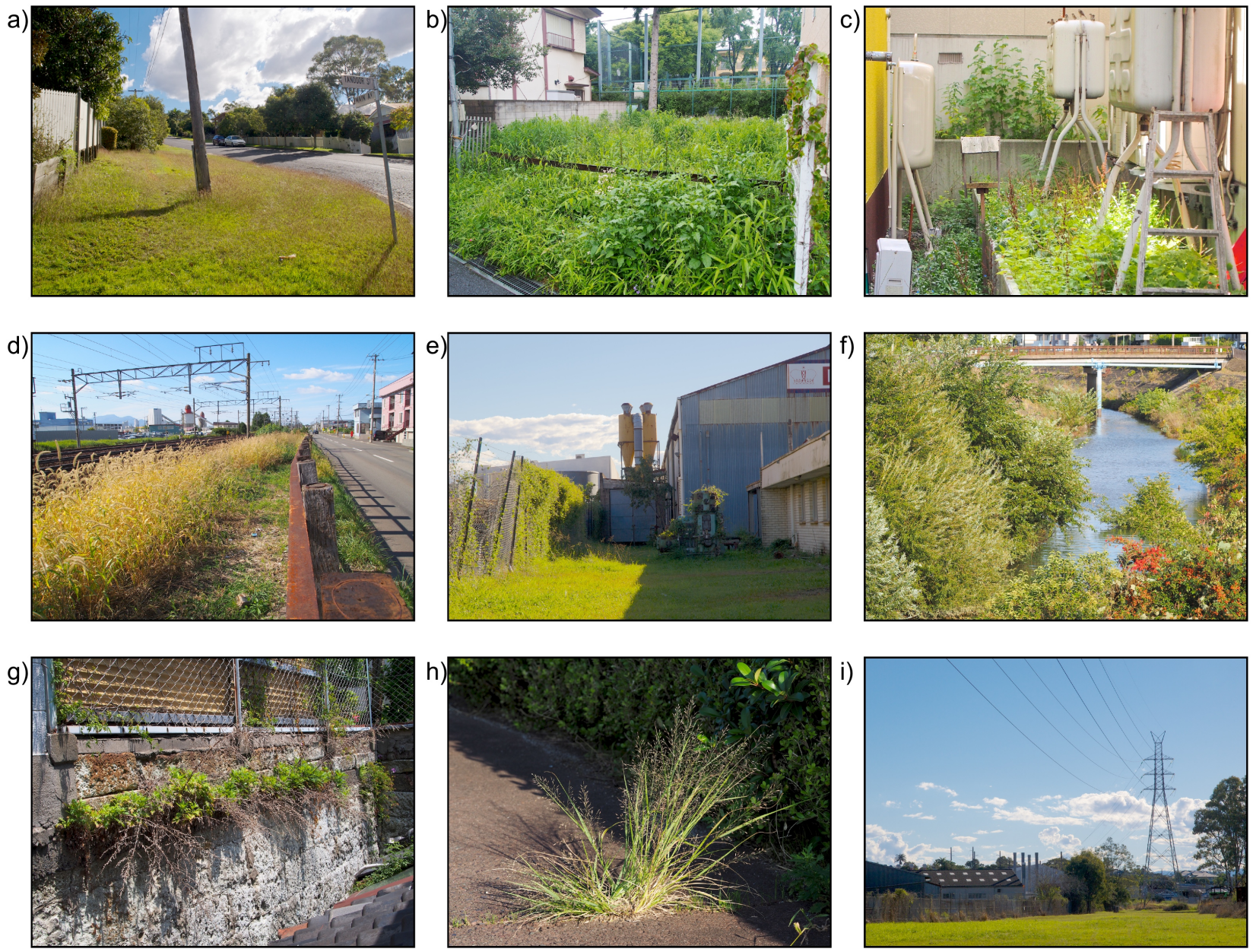

Figure 1 Photographs of informal greenspace types following the typology presented in Table 1. a) Street verge, covered in spontaneous herbal vegetation (Brisbane, Australia); b) Lot, formerly residential with perfunctory access restriction (Tōkyō, Japan), c) Gap, space between three buildings with spont. herbal vegetation used by birds (Sapporo, Japan); d) Railway, annual grass verge between rail track and street; e) Brownfield, spont. vegetated industrial space around abandoned factory (Brisbane); f) Waterside, spont. vegetation on banks and deposits in highly modified river (Nagoya, Japan); g) Structural, spont. vegetation growing out of vertical, porous retaining wall (Tōkyō); h) Microsite, grass growing spont. growing out of crack in the pavement (Nagoya); i) Powerline, vegetated right of way underneath high voltage powerline (Brisbane); (Rupprecht \& Byrne, 2014a). 
Table 1 Informal urban greenspace typology (modified from Rupprecht \& Byrne, 2014a)

\begin{tabular}{|c|c|c|c|c|}
\hline IGS & Examples & Description & Management & $\begin{array}{c}\text { Common } \\
\text { substrates }\end{array}$ \\
\hline Street verges & $\begin{array}{l}\text { Roadside verges, } \\
\text { roundabouts, tree } \\
\text { rings, informal } \\
\text { trails and footpaths }\end{array}$ & $\begin{array}{l}\text { Vegetated area within } 5 \mathrm{~m} \text { from street not in another IGS category; mostly } \\
\text { maintained to prevent high and dense vegetation growth other than street } \\
\text { trees; public access unrestricted, use restricted. }\end{array}$ & $\begin{array}{l}\text { Regular vegetation removal }(>=\text { once } \\
\text { per month); governmental and private } \\
\text { stewardship }\end{array}$ & $\begin{array}{l}\text { Soil, gravel, stone, } \\
\text { concrete, asphalt }\end{array}$ \\
\hline Lots & $\begin{array}{l}\text { Vacant lots, } \\
\text { abandoned lots }\end{array}$ & $\begin{array}{l}\text { Vegetated lot presently not used for residential or commercial purposes; if } \\
\text { maintained, usually vegetation removed to ground cover; public access and } \\
\text { use restricted. }\end{array}$ & $\begin{array}{l}\text { Irregular veg. removal, medium to } \\
\text { long removal intervals; private } \\
\text { stewardship }\end{array}$ & Soil, gravel, bricks \\
\hline Gap & $\begin{array}{l}\text { Gap between walls } \\
\text { or fences }\end{array}$ & $\begin{array}{l}\text { Vegetated area between two walls, fences or at their base; maintenance can } \\
\text { be absent or intense; public access and use often restricted. }\end{array}$ & $\begin{array}{l}\text { Irregular veg. removal; variable } \\
\text { removal intervals; private } \\
\text { stewardship }\end{array}$ & Soil, gravel \\
\hline Railway & $\begin{array}{l}\text { Rail tracks, verges, } \\
\text { stations }\end{array}$ & $\begin{array}{l}\text { Vegetated area within } 10 \mathrm{~m} \text { adjacent to railway tracks not in another IGS } \\
\text { category; usually herbicide maintenance to prevent vegetation } \\
\text { encroachment on tracks; public access and use mostly restricted. }\end{array}$ & $\begin{array}{l}\text { Regular veg. removal (monthly to } \\
\text { yearly); corporate or governmental } \\
\text { stewardship }\end{array}$ & Soil, gravel, stone \\
\hline Brownfields & $\begin{array}{l}\text { Landfill, post-use } \\
\text { factory grounds, } \\
\text { industrial park }\end{array}$ & $\begin{array}{l}\text { Vegetated area presently not used for industrial or commercial purposes; } \\
\text { usually no or very infrequent vegetation removal and maintenance; public } \\
\text { access and use mostly restricted. }\end{array}$ & $\begin{array}{l}\text { Irregular veg. removal, long removal } \\
\text { intervals; corporate and governmental } \\
\text { stewardship }\end{array}$ & $\begin{array}{l}\text { Soil, gravel, } \\
\text { concrete, asphalt }\end{array}$ \\
\hline Waterside & $\begin{array}{l}\text { Rivers, canals, } \\
\text { water reservoir } \\
\text { edges }\end{array}$ & $\begin{array}{l}\text { Vegetated area within } 10 \mathrm{~m} \text { of water body not in another IGS category; } \\
\text { occasional removal of vegetation to maintain flood protection and structural } \\
\text { integrity; public access and use often possible with some restrictions. }\end{array}$ & $\begin{array}{l}\text { Irregular veg. removal, } \\
\text { long removal intervals; governmental } \\
\text { stewardship }\end{array}$ & $\begin{array}{l}\text { Soil, stone, } \\
\text { concrete, bricks }\end{array}$ \\
\hline Structural & $\begin{array}{l}\text { Walls, fences, } \\
\text { roofs, buildings }\end{array}$ & $\begin{array}{l}\text { Overgrown human artifacts; often vertical; occasional removal of vegetation } \\
\text { to maintain structural integrity; public access and use mostly restricted. }\end{array}$ & $\begin{array}{l}\text { Irregular veg. removal, } \\
\text { medium to long removal intervals; } \\
\text { varying stewardship }\end{array}$ & $\begin{array}{l}\text { Soil, stone, gravel, } \\
\text { wood, metal }\end{array}$ \\
\hline Microsite & $\begin{array}{l}\text { Vegetation in } \\
\text { cracks or holes }\end{array}$ & $\begin{array}{l}\text { Vegetation assemblages in cracks, may develop into structural IGS; } \\
\text { maintenance can be absent or intense }\end{array}$ & $\begin{array}{l}\text { Irregular veg. removal, variable } \\
\text { removal intervals; variable } \\
\text { stewardship }\end{array}$ & $\begin{array}{l}\text { Deposits, soil, } \\
\text { stone, conrete }\end{array}$ \\
\hline $\begin{array}{l}\text { Power } \\
\text { line }\end{array}$ & $\begin{array}{l}\text { Powerline rights of } \\
\text { way }\end{array}$ & $\begin{array}{l}\text { Vegetated corridor under and within } 25 \mathrm{~m} \text { of powerlines not in another IGS } \\
\text { category; vegetation removed periodically to prevent high growth; public } \\
\text { access and use mostly unrestricted. }\end{array}$ & $\begin{array}{l}\text { Regular veg. removal (less than } \\
\text { yearly); } \\
\text { utility or governmental stewardship }\end{array}$ & Soil \\
\hline
\end{tabular}


Publications were systematically analyzed for findings on the role of IGS for urban biodiversity, characteristics of each published study (year of publication, location, Köppen-Geiger climate type, IGS description, target species group, species number or range found (where available) and human impact). We also analyzed publication patterns across all research papers, such as temporal trends, spatial patterns, studied IGS types, taxa, climate types, human impact types, and key authors. Results are presented in tables and figures to efficiently present and synthesize findings from the large number of articles, following similar presentation and analysis methods used in recent literature reviews (e.g., Garden et al., 2006). Analysis of distribution among different climate zones followed an updated version of the Köppen-Geiger system (Kottek et al., 2006) using a KMZ-file (Wilkerson and Wilkerson, 2010). Principal and co-authorship was used to identify key authors who contributed multiple articles.

\section{Results}

We found a total of 174 papers, consisting of 172 original journal articles widely distributed across 90 journals, one book chapter and one Masters' thesis. Journals publishing the most research papers were Urban Ecosystems, followed by Landscape and Urban Planning, Diversity and Distributions, Biological Conservation, then Journal of the Japanese Institute of Landscape Architecture (Table 2). This demonstrates that a variety of journals and scholars share an interest in this topic.

Table 2 Journals containing most papers on IGS biodiversity

\begin{tabular}{lrr} 
Journals containing two or more papers & Number of papers & Percent of papers* \\
\hline Urban Ecosystems & 22 & $13 \%$ \\
Landscape and Urban Planning & 19 & $11 \%$ \\
Diversity and Distributions & 7 & $4 \%$ \\
Biological Conservation & 6 & $3 \%$ \\
Journal of the Japanese Institute of Landscape & 5 & $3 \%$ \\
Architecture & 4 & $2 \%$ \\
Urban Ecology & $4 \%$ \\
* Percentage does not add up to $100 \%$ as only journals with $>3$ papers are shown
\end{tabular}

\subsection{Role of IGS for urban biodiversity}

Research papers focused on three main topics: (a) value of IGS for conservation (94 papers), (b) factors influencing IGS biodiversity (80), and (c) non-indigenous species found in IGS (37). A table shows a summary of findings for the individual papers, including their publication year, location, IGS type, climate zone, a detailed IGS description, details regarding human impact, the target species group, number of species found (if available), and noteworthy comments about IGS and its value (Appendix B). We discuss the main findings and their implications after summarizing the results and examining trends in the literature.

\section{1.(a) Value of IGS for conservation}

The value of IGS for conservation was emphasized by just over half the papers (53\%). Researchers reported high species numbers across different IGS types and taxa (e.g., Brandes, 2001; Geibert, 1980; Muratet et al., 2007; Tan, 2010). Some IGS harbors rare species (Dana, 2002; Eyre et al., 2003; Gilbert, 1990; Kadas, 2006) and was thus characterized as a wildlife refuge (Kantsa et al., 2013). The contribution of IGS to biodiversity was often assessed in comparison to other areas and habitats. Urban IGS can have higher species richness or diversity than rural areas (Mason et al., 2006; Meek et al., 2010; Ray and George, 2009), lawns and forest (Robinson and Lundholm, 2012), 
or ornamental plantings (Fründ et al., 1988; Vakhlamova et al., 2014), although non-indigenous species may account for the difference (Ray and George, 2009). IGS can provide valuable habitat (Brandes, 1992; Brown and Sawyer, 2012; Colla and Willis, 2009; Dallimer et al., 2012b; Rebele, 1988; Winter, 2013), and occasionally serve as a substitute for natural habitats (Joger, 1988; Kaupp et al., 2004). It also represents an opportunity for urban residents to experience nature as a 'naturalcum-cultural' heritage (Jim and Chen, 2011, 2010, 2008) or as a source of edible plants (e.g. in urban foraging) (Diaz-Betancourt et al., 1999; Rapoport et al., 1995). While IGS can have additional benefits for residents, this topic has been covered in our earlier review (Rupprecht and Byrne, 2014b). We will return to how and why IGS can provide habitat and other benefits in the discussion.

\section{1.(b) Factors influencing IGS biodiversity}

A wide variety of factors influencing IGS biodiversity were identified in the research papers. Scholars most commonly cited management practices and their negative impact on diversity (e.g., Helden and Leather, 2004; Jantunen et al., 2006; Jim and Chen, 2010; Vakhlamova et al., 2014), even though habitat value for some indigenous species may depend on such management (Nemec et al., 2011). Less direct disturbance may contribute to higher species numbers (Dana, 2002; Schadek et al., 2008) by preserving vegetation communities valuable for conservation (Lenzin et al., 2007). Different aspects of vegetation were regarded as important, especially vegetation structure (Fernandez-Juricic, 2000; Florencia Carballido et al., 2011; Geibert, 1980; Strauss and Biedermann, 2006), vegetation as a food source (Eremeeva and Sushchev, 2005; Kazemi et al., 2011; Small et al., 2006; Tommasi et al., 2004), and vegetation (including tree) cover (Ichinose, 2006; Itagawa et al., 2010; Luther et al., 2008; Pennington et al., 2008). Biodiversity was found to increase with site age (Crowe, 1979; Jantunen et al., 2006; Kim and Lee, 2005), distance from the city center (Vakhlamova et al., 2014; Wahlbrink and Zucchi, 1994; Zorenko, 2003), and habitat diversity (Dallimer et al., 2012b; Murgui, 2009), while it was negatively affected by sealed site surface (e.g., hard surfaces such as asphalt that can impede seedling growth) and substrate (Dallimer et al., 2012b; Francis and Hoggart, 2008; Godefroid et al., 2007).

\section{1.(c) Non-indigenous species found in IGS}

Many researchers reported that they found high numbers of non-indigenous species across different IGS types (Bigirimana et al., 2011; Garcillán et al., 2009; Kim et al., 2004; Ray and George, 2009), particularly in New Zealand (Asmus and Rapson, 2014; de Neef et al., 2008), China (Gong et al., 2013; Zhao et al., 2009), and the USA (Pennington et al., 2010; Stylinski and Allen, 1999). This finding contrasts with papers reporting low numbers of such species (Catterall et al., 2010), particularly in South-Africa (Cilliers and Bredenkamp, 2000, 1999) and Europe (Bornkamm, 2007; Celesti-Grapow and Blasi, 1998). While some researchers reported that non-indigenous species dominated (Asmus and Rapson, 2014; Crawford, 1979; Gantes et al., 2014; Stylinski and Allen, 1999), others found little evidence for competition (Celesti-Grapow et al., 2006). Some researchers asserted that naturalized species may enhance urban biodiversity (Zerbe et al., 2004), provide ecosystem services (Meek et al., 2010), and are of socio-cultural significance as they may possess various desirable ecological and aesthetic qualities (Chmaitelly et al., 2009). Non-indigenous species composition may also be used to trace historical patterns of introduction (Dehnen-Schmutz, 2004). While railway IGS was found to function as a corridor for grassland plants, it was not found to provide any bonus to invasive species (Penone et al., 2012).

\subsection{Trends and patterns in the literature}

\section{2.(a) Temporal trends}

The earliest study included in our review was published in the 1960s (Bornkamm, 1961). Earlier studies not appearing in our systematic search were reported in a post-war botanical study of 
bombed cities (Lachmund, 2003). Over the last 15 years, the number of publications on IGS and urban biodiversity has risen, with $70 \%$ of all research papers published since 2004 (Fig. 2). This increasing interest could be related to ongoing global urbanization, the rise of urban ecology (Douglas and Goode, 2011), as well as increasing recognition of the interconnections between biodiversity and the well-being of urban residents (Dallimer et al., 2012a; Dearborn and Kark, 2010; Keniger et al., 2013).

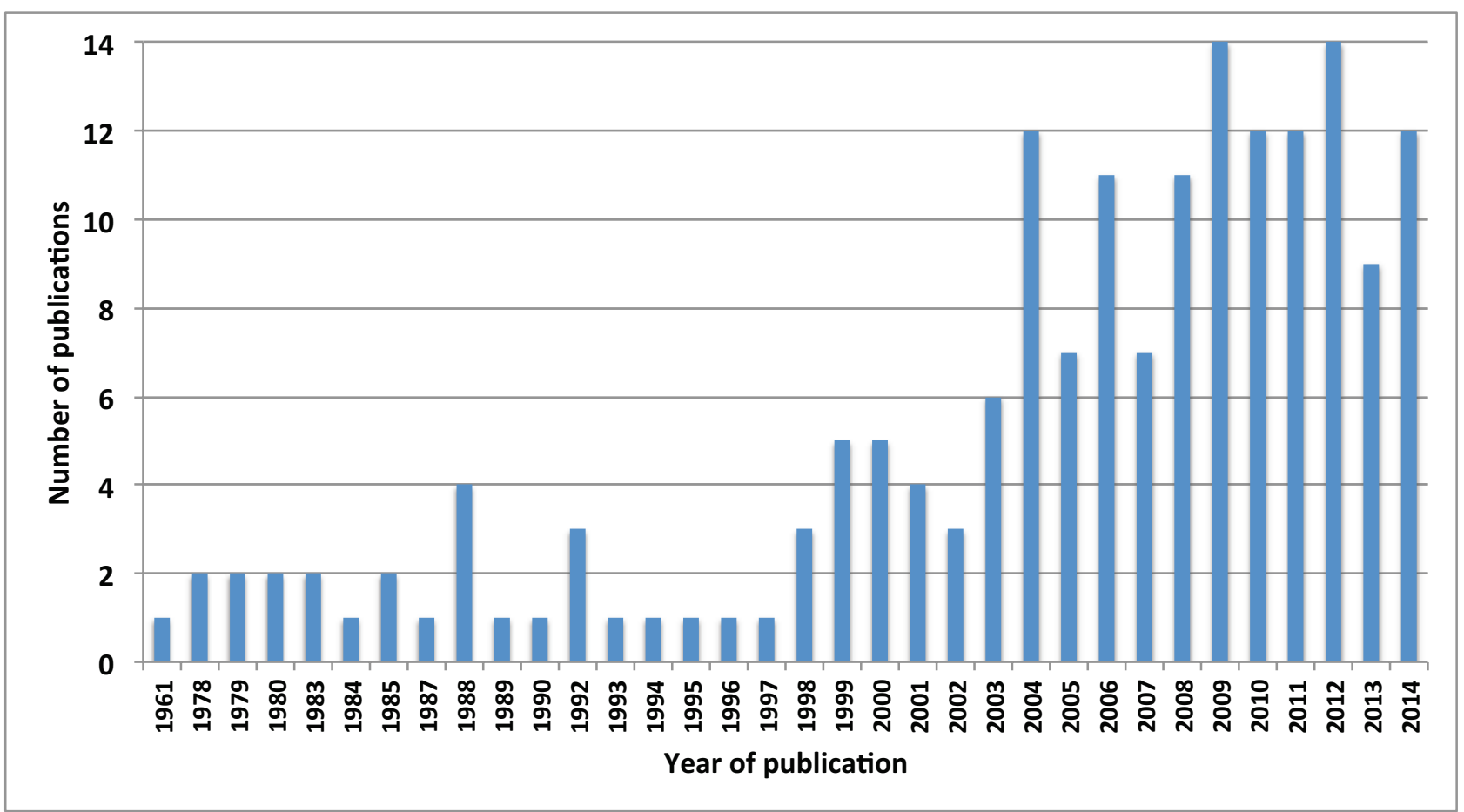

Figure 2 Publication history of papers on IGS biodiversity 


\section{2.(b) Spatial and linguistic patterns}

The geographic distribution of study locations in single-country papers shows a heavy bias towards four countries: Germany (23 papers, $13 \%$ ), the UK (22 papers, 13\%), the US (18 papers, 10\%), and Japan (15 papers, 9\%) (Fig. 3). Few research papers compared IGS in different geographical contexts, causing a geographic concentration of knowledge about IGS especially in Europe (Fig. 4). Papers from countries with increasing research output, such as China, are rare - a result possibly caused by our limited capacity to search other languages, which we discuss in more detail later. Research papers written in German (14 papers, 8\%) and Japanese (eight papers, 5\%) made up 13\% of all papers. Three German language papers studied IGS in Switzerland, while another one compared IGS in multiple countries.

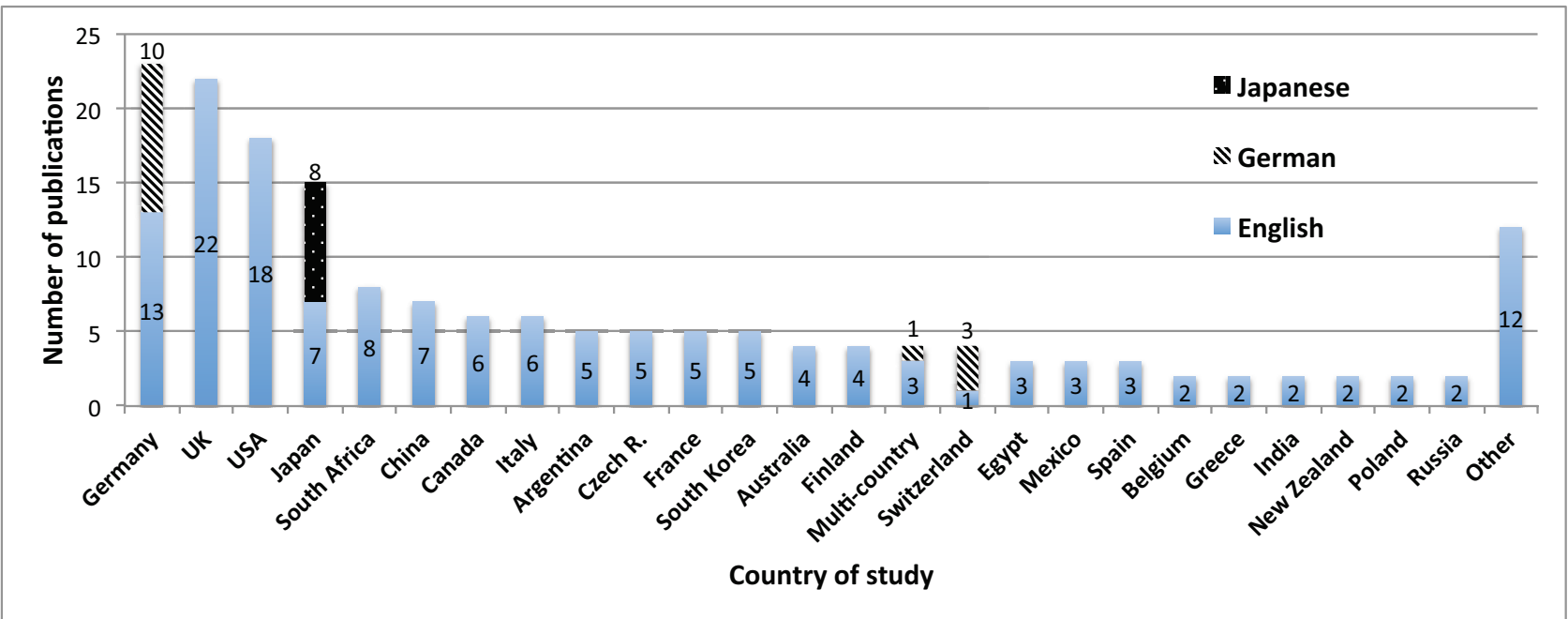

Figure 3 Geographic and linguistic distribution of papers on IGS biodiversity

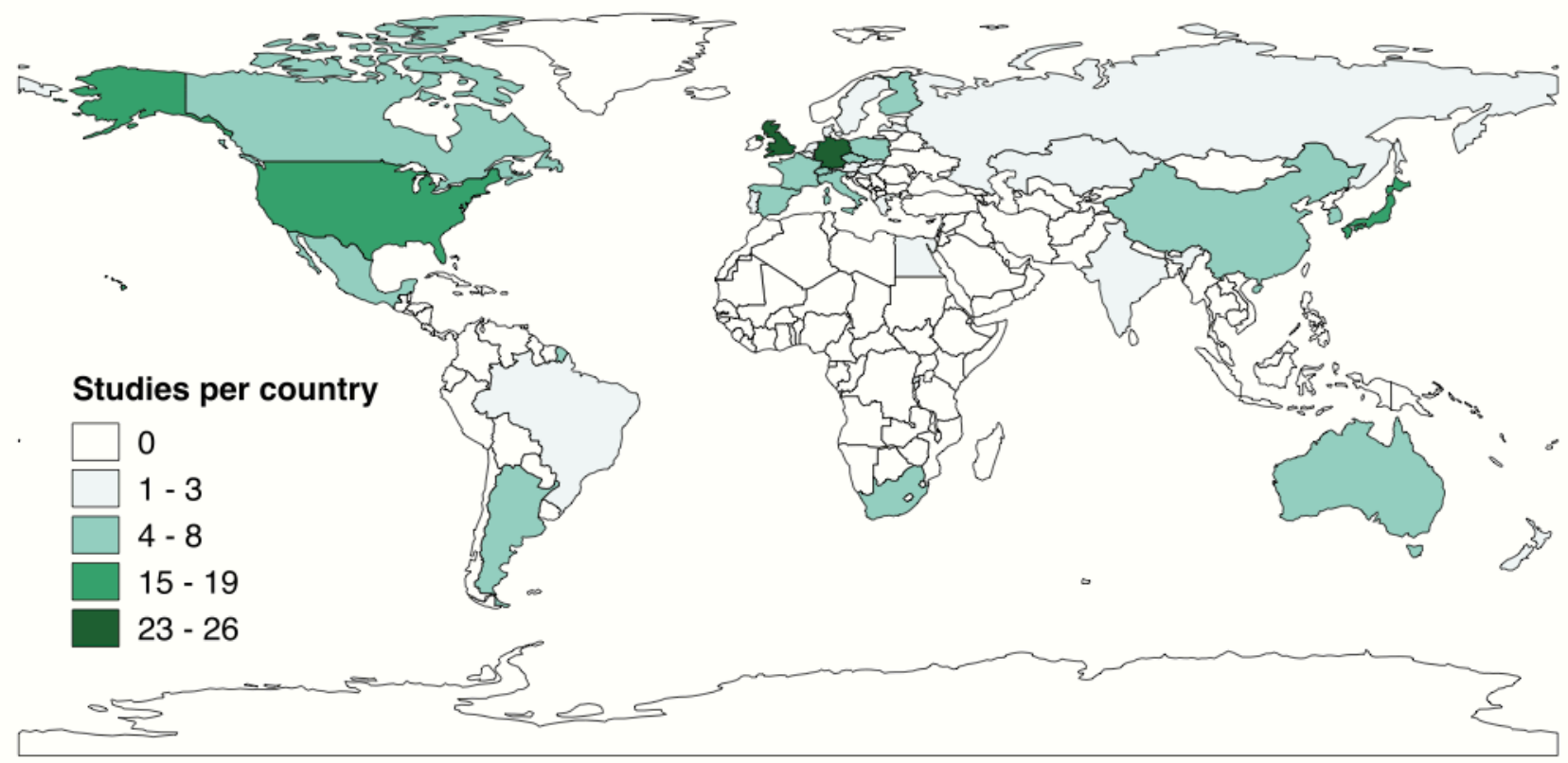

Figure 4 Map of IGS biodiversity studies per country (including multi-national studies) 


\section{2.(c) IGS types studied}

Research papers that targeted at least two different types of IGS accounted for a third of all papers (61 papers, 35\%, Fig. 5). Brownfield and waterside were the most commonly studied IGS types in single-type studies (27 papers or $16 \%$ each), followed by verges (22 papers, 13\%) and structural IGS (17 papers, 10\%). Gap, powerline and microsite IGS were almost completely absent from the literature. While some articles compared between types (Brandes, 2001), the number of IGS types included in most multi-IGS-type papers was limited, which in turn limited potential comparisons. As mentioned above, different authors may also refer to similar spaces by different names (e.g. wasteland, derelict land, abandoned lot, vacant lot), which may complicate drawing upon their data for potential future meta-analyses.

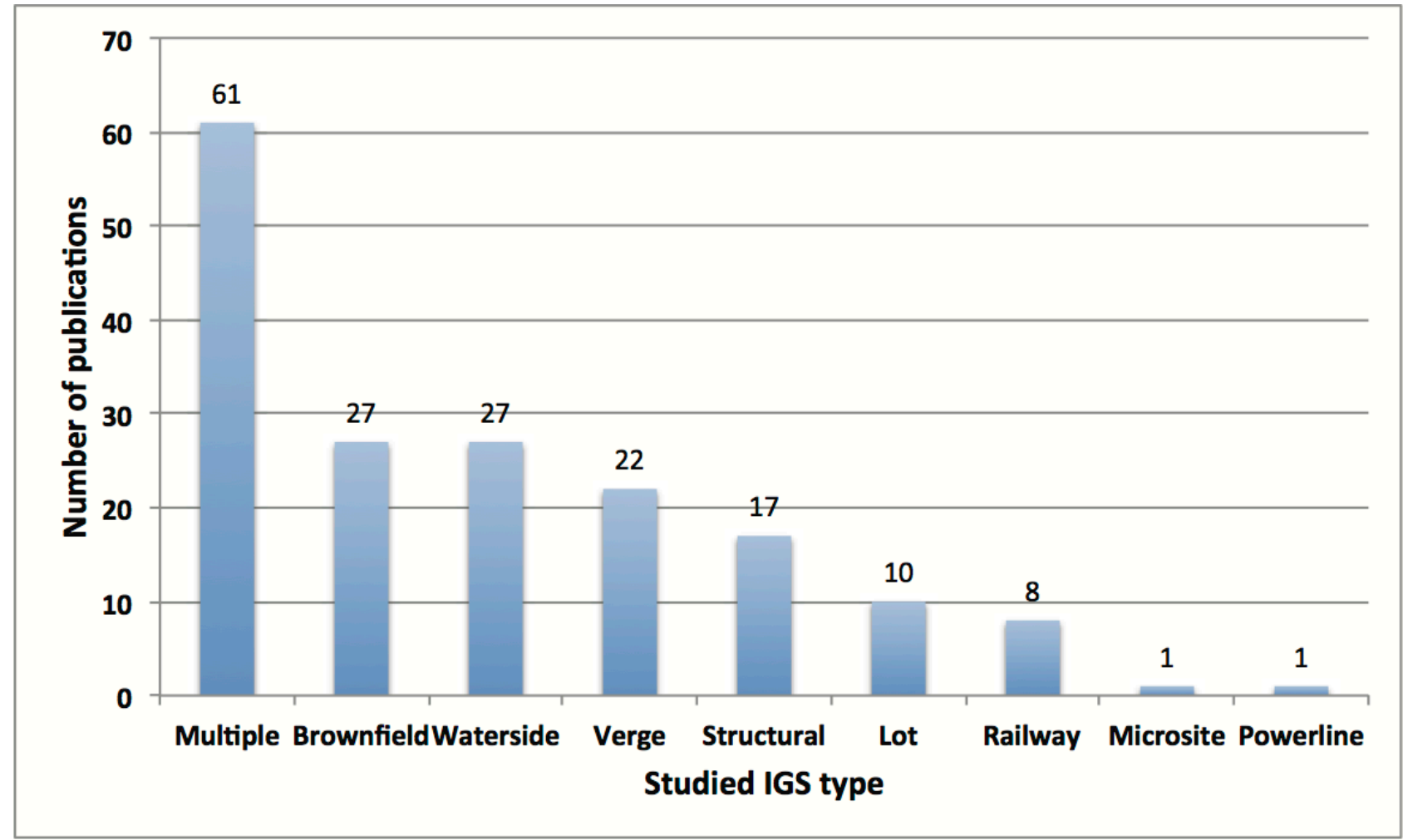

Figure 5 Distribution of papers on IGS biodiversity by studied IGS type

\section{2.(d) Species groups studied}

Vegetation dominated as the target of IGS biodiversity papers. Papers examining vegetation in general were most common (79 papers, 45\%, Fig. 6), but researchers also studied various subsets of vegetation, such as vascular plants (5 papers, 3\%), and groups of species not identical with a specific taxon, such as spontaneous or non-native vegetation (4 papers or $2 \%$ each) or edible weeds ( 2 papers, $1 \%)$. With regard to animals, birds (24 papers, 14\%) and beetles ( 9 papers, 5\%) were most frequently studied. 


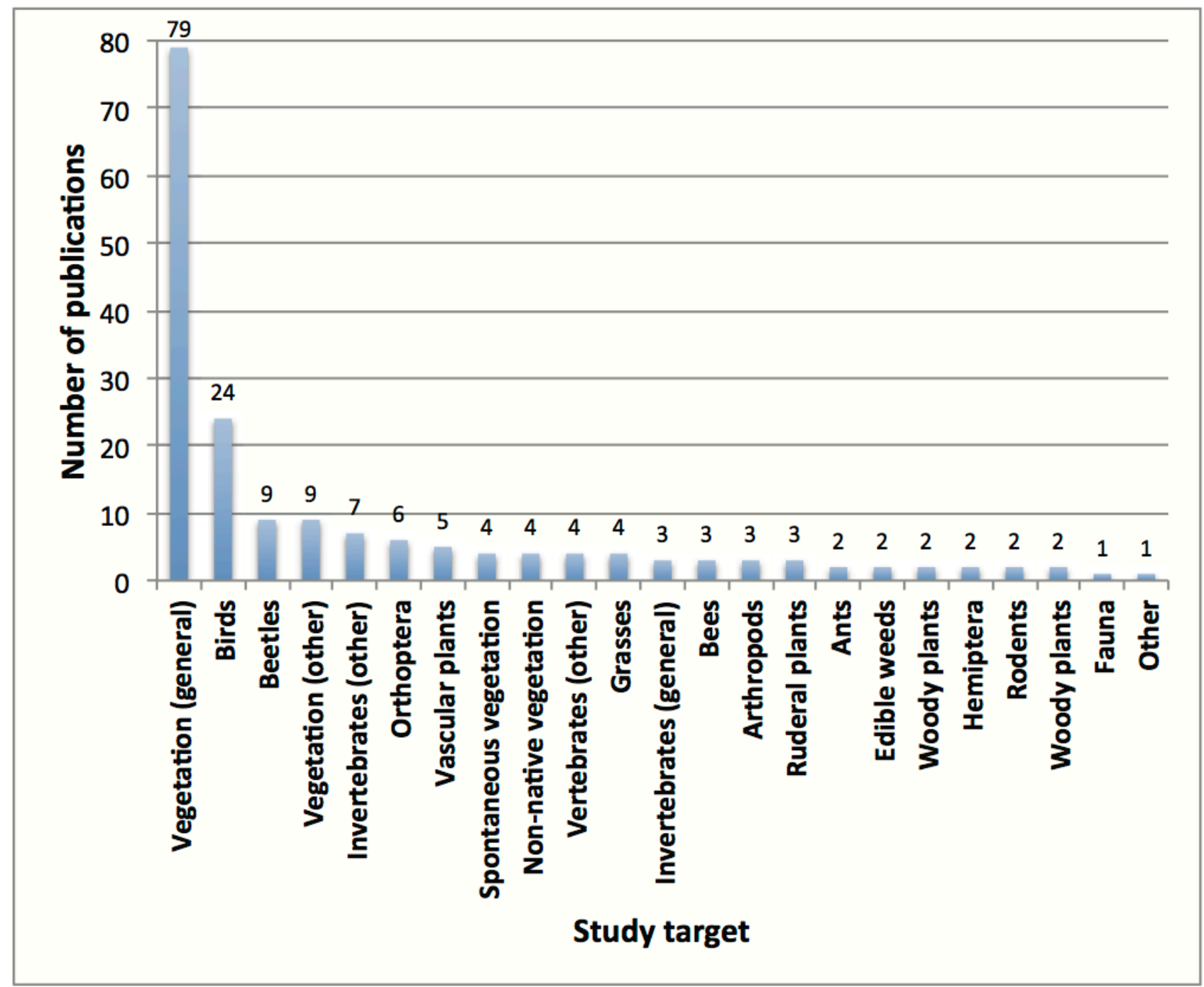

Figure 6 Distribution of papers on IGS biodiversity by studied species group

\section{2.(e) Human impact}

Researchers have found a variety of anthropogenic influence types affect IGS. The most commonly mentioned types were the design of the site and general maintenance/management (29 papers, 17\%, Fig 7.), followed by vegetation removal in the form of mowing, cutting or weeding (26 papers, $15 \%$ ) and pollution of various kinds (24 papers, 14\%). Aspects of site design such as substrate type (e.g., bricks, gravel) were emphasized as particularly important for waterside (Francis and Hoggart, 2012) and structural IGS (Jim and Chen, 2011). 


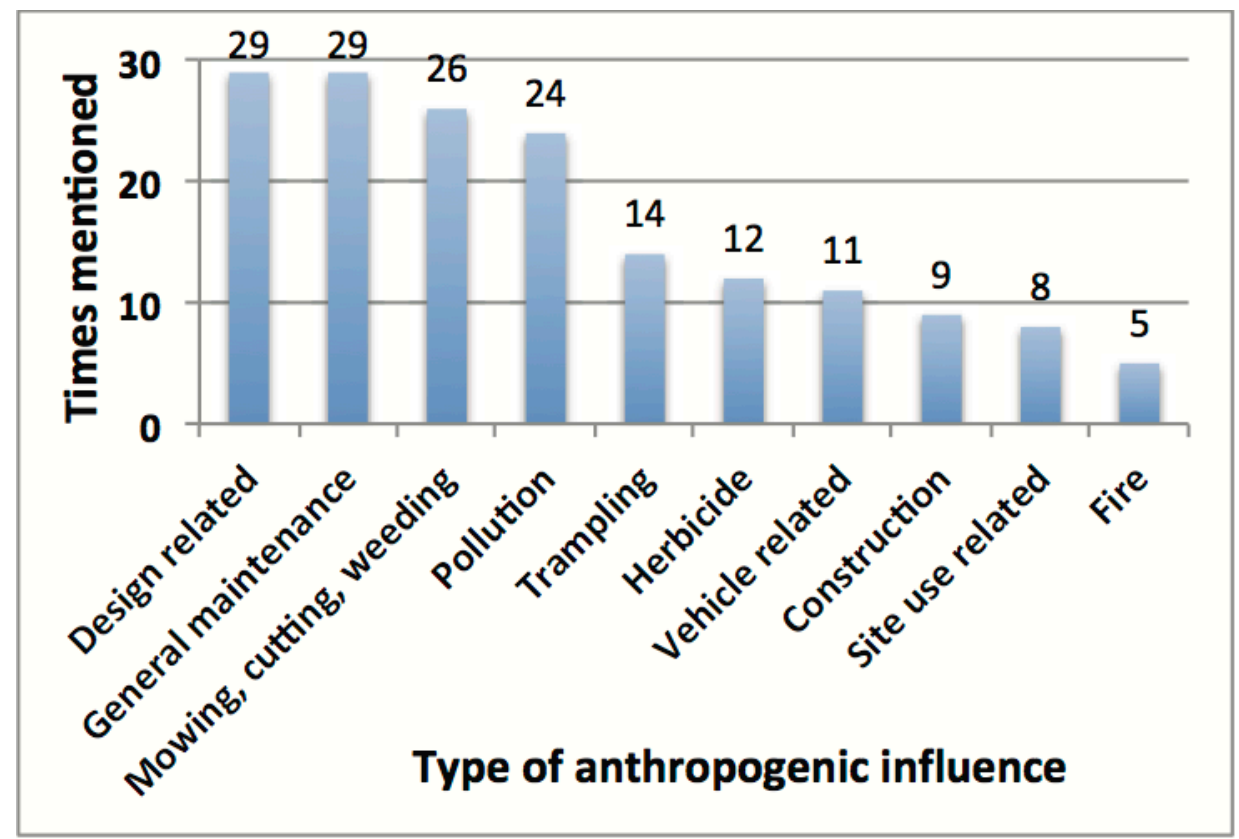

Figure 7 Most commonly mentioned types of human impact on IGS

\section{2.(f) Climate zone distribution}

Research papers showed a strong bias towards warm, temperate, and fully humid climate zones, particularly Köppen-Geiger climate type Cfb (79 papers, 45\%, Fig. 8), followed by Cfa (29 papers, $17 \%$ ) and Dfb (18 papers, 10\%). This bias likely results from the biased geographic distribution of IGS biodiversity research sites and/or researchers (i.e. North America, Europe, and Japan).

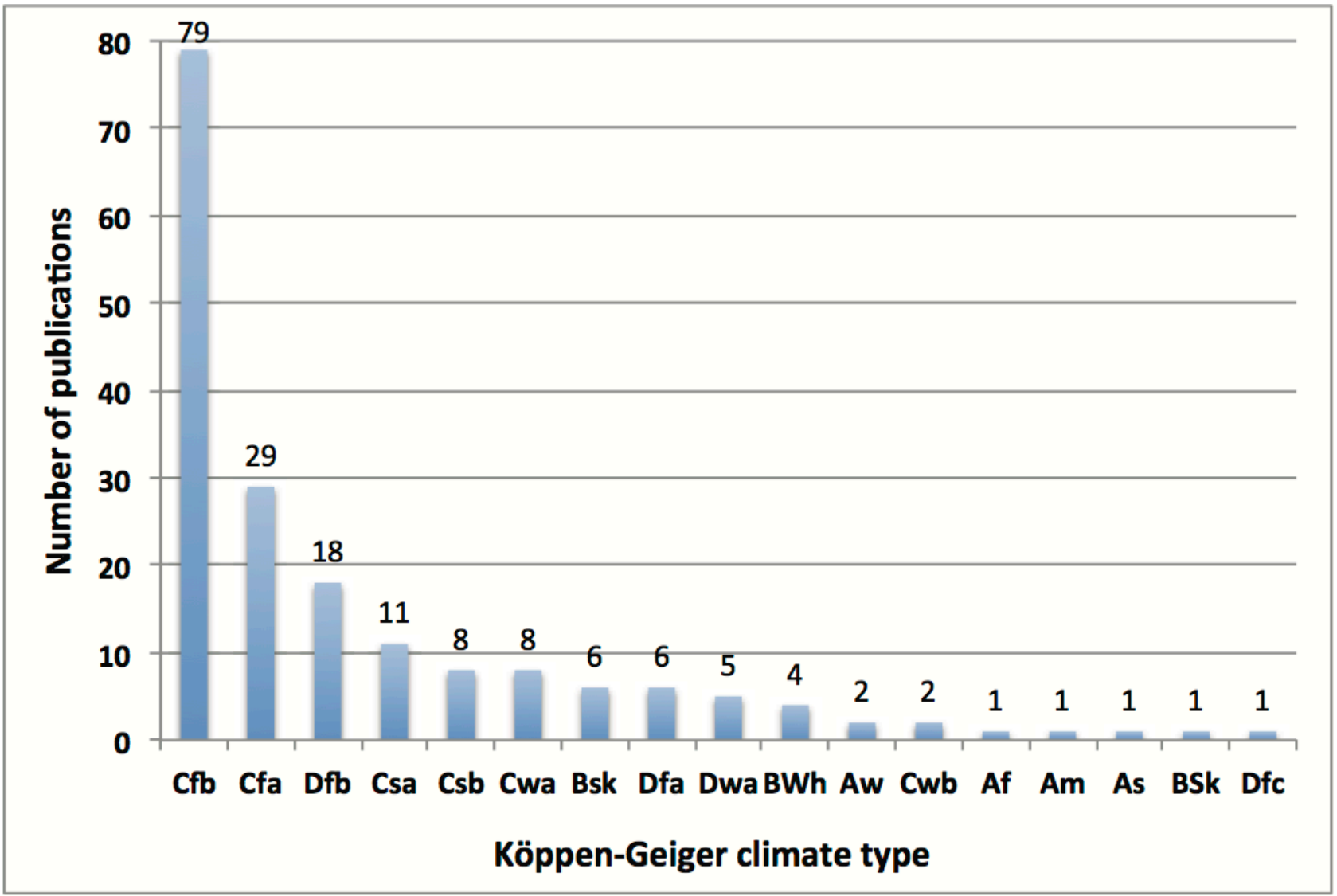

Figure 8 Distribution of papers on IGS biodiversity by Köppen-Geiger climate zone 


\section{2.(g) Key authors}

Five scholars contributed four or more of the research papers reviewed. Petr Pyšek analyzed trends in urban vegetation diversity and composition over three decades (Pyšek et al., 2004) and coauthored several papers on European IGS vegetation (Celesti-Grapow et al., 2006; Prach et al., 2014; Prach and Pyšek, 2001; Pyšek et al., 2003). Cilliers and Bredenkamp studied the ruderal vegetation of railway reserves, vacant lots, and road verges of South Africa (Cilliers and Bredenkamp 1998, 1999a, 1999b, 2000). Brandes worked on ruderal vegetation of railway stations, walls, and that of a small town (Brandes, 2001, 1992, 1983; Oppermann and Brandes, 1993). Francis (with Hoggart) examined river walls and the influence of substrate on vegetation (Francis, 2011; Francis and Hoggart, 2009, 2008; Hoggart et al., 2012). Ten scholars contributed three research papers as authors or co-authors, including Bornkamm (Abd El-Ghani et al., 2011; Bornkamm, 2007, 1961), Jim and Chen (Jim and Chen, 2011, 2010, 2008), Kim (Kim, 2013; Kim et al., 2004; Kim and Lee, 2005), Kowarik (Weber et al., 2014; Westermann et al., 2011; Zerbe et al., 2004), Muratet (Maurel et al., 2010; Muratet et al., 2008, 2007), Pennington (Pennington et al., 2010, 2008; Pennington and Blair, 2011), and Small (Angold et al., 2006; Small et al., 2006; Small and Sadler, 2003). Twenty-six scholars contributed two research papers as authors or co-authors.

\section{Discussion}

\subsection{Role of IGS for biodiversity}

Researchers have found that IGS plays an important role for urban biodiversity because it provides a range of species with valuable habitat, as our systematic review of 174 research papers has shown. This result is consistent with an earlier review by Bonthoux and colleagues (2014), who analyzed 37 papers and reported that the diverse local features of wasteland encourage diverse communities. Our results further emphasize that the value of IGS depends on its local context.

IGS can provide habitat of a specific type otherwise scarce or absent in an urban area, for example as structural IGS in the form of vegetated brick walls (Brandes, 1992). It may also resemble ecosystems that were once dominant, but have declined as a result of landscape changes, such as verges and brownfields with characteristics similar to sand plain grassland (Brown and Sawyer, 2012). By providing stepping-stones that support dispersal in urban areas, informal greenspaces form part of a habitat network and enhance sustainability of metapopulations, as Kaupp and colleagues (2004) reported for beetles nesting on spontaneously vegetated roofs. In addition to such direct contributions to conservation, the localized socio-ecological aspects of IGS can produce indirect benefits. In Hong Kong, spontaneous strangler figs may inspire awe in the viewer (Jim and Chen, 2011), thus inspiring ecological awareness, and increasing the possibility of support for nature conservation initiatives (Dunn et al, 2006). In Bariloche (Argentina), where malnutrition poses a serious problem, 1.3 tons of edible weeds may be harvested per hectare of vacant urban and suburban lots (Diaz-Betancourt et al., 1999), thus reducing the use of protected areas for unsustainable livelihood practices. Such socio-ecological aspects can be important for biodiversity because urban residents' contact with nature likely influences conservation efforts beyond the local urban area (Dunn et al., 2006; Millard, 2010; Miller, 2005). However, the main value of IGS for conservation remains context-specific (e.g., which species benefit the most, and which likely do not? Which type of IGS may provide which kind of threatened habitat type?). As Bonthoux and colleagues (2014) argued, wastelands are not a uniform environment. The same is true for IGS, which means planners and environmental managers must depend on localized knowledge to effectively integrate IGS into urban conservation strategies - a point we return to shortly.

Factors influencing the biodiversity of IGS are characterized by two aspects, (i) the importance of local features and (ii) the strong impact of management practices. Regarding the importance of local features, our results are consistent with the findings of Bonthoux and colleagues (2014). Our results 
further emphasize the importance of vegetation structure, vegetation as a food source, vegetation cover, site age, and soil - in other words, characteristics that require planners to have a thorough understanding of the local conditions in order to adopt appropriate conservation strategies (as discussed above). The impact of management on IGS biodiversity was a widely reported issue in the papers we reviewed, but was in contrast not reviewed by Bonthoux and colleagues (2014).

The expanded scope of our review casts a new light on the importance of maintenance practices and their negative impact on diversity (Cilliers and Bredenkamp, 1998; Helden and Leather, 2004; Jantunen et al., 2006; Jim and Chen, 2010; Namba et al., 2010; Vakhlamova et al., 2014; Yamato et al., 2004). IGS, according to the definition used in this review (Rupprecht and Byrne, 2014a, 2014b), is neither formally recognized, nor its vegetation managed by its owner for agriculture, forestry, gardening, or recreation. Yet various forms of maintenance (e.g., mowing, herbicide spraying) are still regularly carried out (see above). Maintenance generally reduces vegetation structure and complexity, in turn limiting the amount of food and shelter IGS can provide. This may benefit pioneer and opportunistic species, but could make IGS less valuable for specialists. Some maintenance may be necessary for utilizing the space (e.g., keeping verge vegetation from blocking motorists' line of sight (Brown and Sawyer, 2012)). However, as Hard (2001) pointed out, both conservation-related and formal vegetation management in cities is ecologically and functionally flawed: spontaneous vegetation is 'managed' using high levels of money, labor and herbicides to protect abstract notions of aesthetics or risk minimization. Research by Nassauer has demonstrated how aesthetics and social norms are important drivers for vegetation management (1988; 1992; Nassauer et al., 2009), and as a result a perceived absence of management may signal a lack of care (Nassauer, 1988), with flow-on impacts for biodiversity.

Such socially constructed ideals of greenspace (Lossau and Winter, 2011) and the notion that cities are devoid of nature (long since dispelled by urban ecologists) may be reasons why IGS is often viewed negatively and associated with decline (Corbin, 2003; Rall and Haase, 2011). To unlock the potential of IGS to contribute to specific conservation goals, we may need to adapt management practices accordingly. Brown and Sawyer (2012) provide examples for such adaptations in the management of roadsides resembling sand plain grassland: changing mowing regimes to allow the grasses to flower and mature seed could enhance the presence of rare species, while adjustments to mowing height and width aid perennial species. This example demonstrates that management adaptation is an intricate process. For such adaptions to succeed, we need to understand local IGS conditions as well as the requirements of the species we aim to conserve.

Rare indigenous species have been found in IGS (Dana, 2002; Eyre et al., 2003), but so have nonindigenous and invasive species (Asmus and Rapson, 2014) - an aspect that affects IGS biodiversity management. Urban areas are characterized by challenging environmental conditions that not all species are able to tolerate. While modified maintenance regimes may increase the number of threatened species in IGS, even non-indigenous species that can adapt well to urban environments may enhance biodiversity or provide ecosystem services. For example, Zerbe and colleagues (2004) reported that non-indigenous vascular plants in industrial, road and railway sites contribute close to a third of urban plant biodiversity in Chonju, South Korea. Moreover, Meek and colleagues (2010) drew upon the concept of 'novel ecosystems' (Hobbs et al., 2006) to argue that where restoration to historic conditions is not feasible, management should make use of nonindigenous species to provide ecosystem functions. Importantly, IGS does not replace formal green space such as parks, gardens and conservation areas. Rather, IGS is a liminal, hybrid, socioecological entity that provides habitat for plants and animals as well as opportunities for urban residents to interact with and experience nature (Rupprecht et al., in press; Rupprecht et al., 2015; Rupprecht and Byrne, 2014b). Therefore, researchers have suggested spontaneous vegetation could 
be understood as the "de facto native vegetation of the city" (Del Tredici, 2010b) because it is always appropriate to site conditions (Kühn, 2006). This affects policy recommendations, discussed in more detail later.

\subsection{Trends and patterns in the literature}

Our results have revealed a strong bias in the reviewed IGS literature towards specific regions (Europe, the USA, and Japan) and climate zones (temperate and humid such as Cfb, Cfa, and Dfb). One limitation of our review was our capacity to search other languages besides English, German, and Japanese. This limitation likely contributed to the spatial bias we found in the literature. However, papers published in both German and Japanese only accounted for about half of the studies conducted in Germany and Japan, even though the different linguistic distance between English and the two languages (Chiswick and Miller, 2005) makes learning English easier for German researchers than for Japanese researchers. This could suggest that the comparatively low number of English publications on IGS biodiversity may not solely result from missing non-English publications, but could instead indicate an actual gap in our knowledge about IGS biodiversity in these countries. Future reviews should therefore target additional languages to clarify this issue.

If we lack local IGS knowledge, the spatial and climate zone bias is a major concern, because it would impede our ability to devise context-specific conservation measures in regions that are home to large urban populations, such as China, India, South-East Asia, Africa, and South-America. In particular, climate zones A (four studies) and B (11 studies) are severely understudied, but account for $88 \%$ of Africa, $75 \%$ of South America, and almost all of South-East Asia (Peel et al., 2007). Countries in these regions are experiencing both rapid urbanization (UN-HABITAT, 2012) and threatened biodiversity (Zhao et al., 2006). But it is possible that there is a literature on IGS in these climatic zones that has not been explicitly framed around biodiversity conservation. For example, in the megacities of Africa and Asia, there may be an emphasis on food security rather than biodiversity. Urban interstices offer the potential for growing food, especially for socioeconomically marginalized and vulnerable populations, and for growing medicinal herbs. Growing plants valued for their medicinal properties or nutritional benefits does not necessarily diminish biodiversity, and recent studies of urban food gardens have shown that they can be highly biodiverse (Galuzzi et al., 2010; Weinberger, 2013). Therefore, a better knowledge of local IGS could help to devise strategies for preserving urban biodiversity in these areas, which depend on local knowledge to be effective (see above).

Studies on brownfield, waterside, verges, and structural IGS types were the most common, while gap, powerline and microsite IGS are still comparatively understudied. The area of these understudied sites is usually much smaller than that of a vacant lot or brownfield IGS, which may make such sites seem like a less rewarding object of study, and/or present significant methodological challenges. However, the fragmented nature of urban landscapes makes it likely that a high number of such spaces exist within cities. For example, a recent case study suggested that almost 20\% of IGS, or one percent of the surveyed area in Sapporo (Japan) consisted of gap IGS (Rupprecht and Byrne, 2014a) - an amount particularly valuable for conservation in dense urban areas where other greenspace is scarce. These hitherto little-examined IGS types also warrant closer attention because different IGS types differ in their characteristics (Table 1), and may consequently contribute to urban conservation in different ways. A better understanding of gap and microsite IGS may also help planners to create synergies between conservation and greenspace strategies. Specifically, they may be able to act as additional stepping-stones, similar to vegetated roofs (Kaupp et al., 2004), while contributing to the prevention of urban heat-island effects. 
Studies on the vegetation of IGS and its role for birds and beetles were comparatively common, but we presently know little about if and how IGS can be valuable for mammals and reptiles. Studies on ants were also scarce, despite research suggesting vacant lots can feature a distinct species composition and can be richer in species than gardens (Uno et al., 2010). While the limited size of some IGS sites suggest their value could be limited, large or linear sites such as powerline and railway verge IGS could potentially function as movement corridors for large urban wildlife (e.g., coyotes, foxes, deer, kangaroos) connecting urban and peri-urban areas (Rudd et al., 2002).

A number of authors (e.g., Cilliers and Bredenkamp in South Africa, Jim and Chen in Hong Kong, Kim in South Korea) that contributed three of more studies were based outside of Europe, the USA, and Japan. This stands in contrast with the regional bias of the literature. Knowing authors central to the field is important, because it allows us to understand how the current body of IGS literature developed. Additionally, it provides a starting point for studies on the history of IGS biodiversity science. Such authors possess valuable expertise that may help in devising locally adapted conservation strategies. They could also play a role in coordinating future research efforts in their regions, or collaborate for cross-regional and cross-cultural studies as follow-ups to emerging crossnational studies (e.g., Lososová et al., 2011).

\section{Conclusions}

\subsection{Policy recommendations}

Our review of 174 research papers on the role of IGS for biodiversity found that IGS is valuable for conservation, but appropriate management is important for maintaining IGS biodiversity (though this must be inferred because few, if any, studies have demonstrated a statistically significant correlation). We therefore propose to complement the suggestions for conservation and planning of urban wastelands by Bonthoux and colleagues (2014) with a review of maintenance practices. For example, reducing or changing mowing intervals may not only benefit site diversity (Brown and Sawyer, 2012) and save resources, but may also preserve the natural site character that residents cherish (Rupprecht and Byrne, 2014b). However, planners should avoid treating IGS like conservation areas by restricting residents' access, as the diversity of formal and informal uses produces the habitat diversity and local features that make IGS valuable for biodiversity (Bonthoux et al., 2014; Hard, 2001). A thorough understanding of these local features and the local context should inform IGS management, and facilitate integration into urban conservation strategies.

Planners and government agencies need to work with owners of IGS, such as utilities and railway operators, to phase out harmful maintenance practices (e.g., herbicide spraying). Where frequent vegetation maintenance is essential or strongly preferred as a result of residents' preferences (Nassauer et al., 2009), encouraging a conversion of IGS toward recreational green space types such as community gardens may be an option. For example, the power utility Chubu Electric Power invites local residents in Nagoya (Japan) to use land under urban power transmission lines for gardening free of charge, if they in return keep vegetation under a specified height (Rupprecht and Byrne, 2015). The utility profits financially from reduced maintenance expenses, the community enjoys additional recreational opportunities, and birds as well as insects gain a source of food. As such arrangements in particular and the conservation value of IGS in general are determined by its local context, we propose directions for future research to fill the gaps in our local knowledge of IGS biodiversity.

\subsection{Directions for future research}

This review has identified three major gaps in our knowledge of IGS, our localized knowledge of IGS around the world, our knowledge of understudied IGS types, and our knowledge of understudied species groups. First, we know little about IGS biodiversity outside of the temperate 
and humid $\mathrm{Cfb}, \mathrm{Cfa}$ and Dfb climate zones of Germany, the UK, the USA, and Japan. Future research should target IGS biodiversity in South-East Asia, Africa, South America, the Middle East, India, China, and Australia, as well as IGS in the climate zones A and B. Moreover, international comparisons of IGS are rare, and the lack of studies in many regions limits potential meta-analyses and cross-cultural studies. How do different cultural contexts influence the value of IGS for biodiversity, the possibilities for management adaptions, or the potential for hybrid conservationrecreational use? However, it is important to note that this review only examined the available literature in English, German and Japanese. As discussed above, our search also found Spanish and Russian research papers on IGS. A review of literature on IGS in these languages, Chinese, French, Indonesian, Polish and other languages would likely advance our understanding of IGS and help local planners and IGS owners to adapt policies and management.

Second, we lack studies on gap, powerline and microsite IGS as well as comprehensive comparative studies. Future research should address this lack of knowledge by examining some of the following questions. How do gap, powerline or microsite IGS contribute to urban biodiversity? How does their potential contribution compare to other IGS types? How can management practices for these sites be adapted to benefit conservation? Moving to study designs based on a common IGS typology may help us to identify urban habitats important to biodiversity that researchers might have previously overlooked, and could facilitate studies comparing between different IGS types. Research on smaller sites could also redress the paucity of knowledge about IGS in the megacities of Africa and Asia. For instance, it might help to answer questions about whether IGS is meeting food-security needs, such as the harvesting of spontaneous vegetation or the growing of 'bush foods' in the urban interstices, and how in turn this might impact biodiversity.

Third, future studies should investigate the role IGS may play for hitherto scarcely studied species groups. Can IGS benefit mammals, reptiles, or marsupials? Do limited size and human disturbance prevent large animals from using IGS? How does the presence of animals in IGS affect resident perception (e.g., opportunities for nature contact, potential for wildlife conflict)? We need to address these three main gaps in our knowledge. Closing these gaps would be a first step to better understanding the local features of IGS - local features that are key to how IGS contributes to biodiversity, how we should adapt our management of IGS, and how we can integrate IGS into urban conservation strategies. Better knowledge of IGS is crucial for future conservation efforts in urban areas.

Finally, the increasing number of studies on IGS biodiversity provides a growing source of data that future studies could draw upon for meta-analyses. For example, IGS size did not feature prominently as a driving factor for species diversity in the papers we examined in our study despite the important role of this factor in ecological theory (e.g., island biogeography). Future research could analyze a set of IGS studies to explore what role IGS size and related factors such as fragmentation play for the biodiversity of these urban spaces. Another potential target for a metaanalysis would be to quantify (using statistical analysis) the apparent negative relationship between the degree of IGS management and IGS biodiversity - as suggested in some of the literature addressed by this paper. We recognize that this is just one step in a much larger research agenda on IGS. Future studies could address diverse aspects of this understudied component of urban forestry and urban greening. 


\section{References}

Abd El-Ghani, M., Bornkamm, R., El-Sawaf, N., Turky, H., 2011. Plant species distribution and spatial habitat heterogeneity in the landscape of urbanizing desert ecosystems in Egypt. Urban Ecosystems 14, 585-616. doi:10.1007/s11252-011-0188-1

Abd El-Ghani, M., Shehata, M.N., Mobarak, A., Bakr, R., 2012. Factors affecting the diversity and distribution of synanthropic vegetation in urban habitats of the Nile Delta, Egypt. Rend. Fis. Acc. Lincei 23, 327-337. doi:10.1007/s12210-012-0179-z

Angold, P., Sadler, J., Hill, M., Pullin, A., Rushton, S., Austin, K., Small, E., Wood, B., Wadsworth, R., Sanderson, R., 2006. Biodiversity in urban habitat patches. Science of The Total Environment 360, 196-204. doi:10.1016/j.scitotenv.2005.08.035

Asami, K., Yamato, M., Hattori, T., Akamatsu, H., Takeda, Y., 1999. Floristic composition and process of establishment of the Bidens pilosa var. minor-Imperata cylindrica community maintained by cutting on non-arable land in Okinawa Prefecture. Vegetation science 16, 1-11.

Asmus, U., Rapson, G., 2014. Floristic homogeneity underlies environmental diversification of northern New Zealand urban areas. New Zealand Journal of Botany 52, 285-303. doi:10.1080/0028825X.2014.897634

Bacaro, G., Rocchini, D., Duprè, C., Diekmann, M., Carnesecchi, F., Gori, V., Chiarucci, A., 2012. Absence of distance decay in the similarity of plots at small extent in an urban brownfield. Community Ecology 13, 36-44. doi:10.1556/ComEc.13.2012.1.5

Banville, M.J., Bateman, H.L., 2012. Urban and wildland herpetofauna communities and riparian microhabitats along the Salt River, Arizona. Urban Ecosystems 15, 473-488. doi:10.1007/s11252012-0228-5

Bigirimana, J., Bogaert, J., De Canniere, C., Lejoly, J., Parmentier, I., 2011. Alien plant species dominate the vegetation in a city of Sub-Saharan Africa. Landscape and Urban Planning 100, 251-267. doi:10.1016/j.landurbplan.2010.12.012

Bonthoux, S., Brun, M., Di Pietro, F., Greulich, S., Bouché-Pillon, S., 2014. How can wastelands promote biodiversity in cities? A review. Landscape and Urban Planning 132, 79-88. doi:10.1016/j.landurbplan.2014.08.010

Bornkamm, R., 1961. Vegetation und Vegetations-Entwicklung auf Kiesdächern (Vegetation and vegetation development on pebble roofs). Plant Ecol 10, 1-24. doi:10.1007/BF00452954

Bornkamm, R., 2007. Spontaneous development of urban woody vegetation on differing soils. Flora 202, 695-704. doi:10.1016/j.flora.2007.05.004

Brandes, D., 1983. Flora und Vegetation der Bahnhofe Mitteleuropas (Flora and vegetation of train stations in Central Europe). Phytocoenologia 11, 31-115.

Brandes, D., 1992. Flora und Vegetation von Stadtmauern (Flora and vegetation of city walls). Tuexenia 12, $315-339$.

Brandes, D., 2001. Die Ruderalflora der Kleinstadt Lüchow (Niedersachsen) (Ruderal flora of the town Lüchow (Lower Saxony)). Braunschweiger Naturkundliche Schriften 6, 455-483.

Brown, R.N., Sawyer, C.D., 2012. Plant species diversity of highway roadsides in Southern New England. Northeastern Naturalist 19, 25-42. doi:10.1656/045.019.0102

Byrne, J., Portanger, C., 2014. Climate change, energy policy and justice: a systematic review. Analyse \& Kritik 36, 315-343.

Campbell, M.O., 2008. The impact of vegetation, river, and urban features on waterbird ecology in Glasgow, Scotland. J Coastal Res 24, 239-245. doi:10.2112/07-0835.1

Carbó-Ramírez, P., Zuria, I., 2011. The value of small urban greenspaces for birds in a Mexican city. Landscape and Urban Planning 100, 213-222. doi:10.1016/j.landurbplan.2010.12.008

Castillo, E., Priotto, J., Ambrosio, A., Provensal, M., Pini, N., Morales, M., Steinmann, A., Polop, J., 2003. Commensal and wild rodents in an urban area of Argentina. Int Biodeter Biodegr 52, 135-141. doi:10.1016/S0964-8305(03)000330-7

Catterall, C.P., Cousin, J.A., Piper, S., Johnson, G., 2010. Long-term dynamics of bird diversity in forest and suburb: decay, turnover or homogenization? Diversity and Distributions 16, 559-570. doi:10.1111/j.1472-4642.2010.00665.x

Celesti-Grapow, L., Blasi, C., 1998. A comparison of the urban flora of different phytoclimatic regions in Italy. Global Ecol Biogeography 7, 367-378. doi:10.1046/j.1466-822x.1998.00304.x 
Celesti-Grapow, L., Pyšek, P., Jarošík, V., Blasi, C., 2006. Determinants of native and alien species richness in the urban flora of Rome. Diversity and Distributions 12, 490-501. doi:10.1111/j.13669516.2006.00282.x

Cervelli, E.W., Lundholm, J.T., Du, X., 2013. Spontaneous urban vegetation and habitat heterogeneity in Xi'an, China. Landscape and Urban Planning 120, 25-33. doi:10.1016/j.landurbplan.2013.08.001

Ceschin, S., Salerno, G., Bisceglie, S., Kumbaric, A., 2010. Temporal floristic variations as indicator of environmental changes in the Tiber River in Rome. Aquat Ecol 44, 93-100. doi:10.1007/s10452009-9292-1

Chen, X., Wang, W., Liang, H., Liu, X., Da, L., 2014. Dynamics of ruderal species diversity under the rapid urbanization over the past half century in Harbin, Northeast China. Urban Ecosystems 17, 455-472. doi:10.1007/s11252-013-0338-8

Chiquet, C., Dover, J.W., Mitchell, P., 2013. Birds and the urban environment: the value of green walls. Urban Ecosyst 16, 453-462. doi:10.1007/s11252-012-0277-9

Chiswick, B.R., Miller, P.W., 2005. Linguistic distance: A quantitative measure of the distance between English and other languages. Journal of Multilingual and Multicultural Development 26, 1-11.

Chmaitelly, H., Talhouk, S., Makhzoumi, J., 2009. Landscape approach to the conservation of floral diversity in Mediterranean urban coastal landscapes: Beirut seafront. International Journal of Environmental Studies 66, 167-177. doi:10.1080/00207230902859820

Christian, E., Szeptycki, A., 2004. Distribution of Protura along an urban gradient in Vienna. Pedobiologia 48, 445-452. doi:10.1016/j.pedobi.2004.05.009

Cilliers, S.S., Bredenkamp, G.J. 1998. Vegetation analysis of railway reserves in the Potchefstroom municipal area, North West Province, South Africa. South African Journal of Botany 64, 271-280.

Cilliers, S.S., Bredenkamp, G.J. 1999a. Analysis of the spontaneous vegetation of intensively managed urban open spaces in the Potchefstroom Municipal Area, North West Province, South Africa. South African Journal of Botany 65, 59-68.

Cilliers, S.S., Bredenkamp, G.J., 1999b. Ruderal and degraded natural vegetation on vacant lots in the Potchefstroom Municipal Area, Noth West Province, South Africa. South African Journal of Botany $65,163-173$.

Cilliers, S.S., Bredenkamp, G.J., 2000. Vegetation of road verges on an urbanisation gradient in Potchefstroom, South Africa. Landscape and Urban Planning 46, 217-239. doi:10.1016/S01692046(99)00057-2

Clemens, J., Bradley, C., Gilbert, O.L., 1984. Early development of vegetation on urban demolition sites in Sheffield, England. Urban Ecology 8, 139-147. doi:10.1016/0304-4009(84)90011-1

Colla, S., Willis, E., 2009. Can green roofs provide habitat for urban bees (Hymenoptera: Apidae)? Cities and the Environment 2, 1-12.

Corbin, C.I., 2003. Vacancy and the Landscape: Cultural Context and Design Response. Landscape Journal 22, 12-24. doi:10.3368/1j.22.1.12

Crawford, R., 1979. Autumn populations of spiders and other arthropods in an urban landfill. Northwest Science 53, 51-53.

Crowe, T.M., 1979. Lots of Weeds - Insular Phytogeography of Vacant Urban Lots. J Biogeogr 6, 169-181.

Dallimer, M., Irvine, K.N., Skinner, A.M., Davies, Z.G., Rouquette, J.R., Maltby, L.L., Warren, P.H., Armsworth, P.R., Gaston, K.J., 2012a. Biodiversity and the feel-good factor: understanding associations between self-reported human well-being and species richness. BioScience 62, 47-55.

Dallimer, M., Rouquette, J.R., Skinner, A.M.J., Armsworth, P.R., Maltby, L.M., Warren, P.H., Gaston, K.J., 2012 b. Contrasting patterns in species richness of birds, butterflies and plants along riparian corridors in an urban landscape. Diversity and Distributions 18, 742-753.

Dana, E., 2002. Urban vegetation of Almería City—a contribution to urban ecology in Spain. Landscape and Urban Planning 59, 203-216. doi:10.1016/S0169-2046(02)00039-7

Dearborn, D.C., Kark, S., 2010. Motivations for conserving urban biodiversity. Conserv. Biol. 24, 432-440. doi:10.1111/j.1523-1739.2009.01328.x

Dehnen-Schmutz, K., 2004. Alien species reflecting history: medieval castles in Germany. Diversity and Distributions 10, 147-151.

Del Tredici, P., 2010a. Spontaneous Urban Vegetation: Reflections of Change in a Globalized World. Nat Cult 5, 299-315. doi:10.3167/nc.2010.050305

Del Tredici, P., 2010b. Wild urban plants of the Northeast: a field guide. Cornell University Press, Ithaca.. 
De Neef, D., Stewart, G.H., Meurk, C.D., 2008. URban biotopes of Aotearoa New Zealand (URBANZ) (III): Spontaneous urban wall vegetation in Christchurch and Dunedin. Phyton-Ann Rei Bot A 48, 133154.

Desjardins, D., Nissim, W.G., Pitre, F.E., Naud, A., Labrecque, M., 2014. Distribution patterns of spontaneous vegetation and pollution at a former decantation basin in southern Québec, Canada. Ecological Engineering 64, 385-390. doi:10.1016/j.ecoleng.2014.01.003

Diaz-Betancourt, M., Ghermandi, L., Ladio, A., Lopez-Moreno, I., Raffaele, E., Rapoport, E., 1999. Weeds as a source for human consumption. A comparison between tropical and temperate Latin America. Revista de Biología Tropical 47, 329-338.

Dickman, C.R., Doncaster, C.P., 1987. The Ecology of Small Mammals in Urban Habitats. I. Populations in a Patchy Environment. Journal of Animal Ecology 56, 629-640.

Dingaan, M.N.V., Du Preez, P.J., 2013. Grassland communities of urban open spaces in Bloemfontein, Free State, South Africa. Koedoe 55. doi:10.4102/koedoe.v55i1.1075

Douglas, I., Goode, D., 2011. Urban natural histories to urban ecologies: The growth of the study of urban nature, in: The Routledge Handbook of Urban Ecology. Routledge, London, pp. 74-83.

Do, Y., Kim, J.Y., Kim, G.-Y., Joo, G.-J., 2014. Importance of closed landfills as green space in urbanized areas: ecological assessment using carabid beetles. Landscape Ecol Eng 10, 277-284. doi:10.1007/s11355-013-0223-X

Dunn, R.R., Gavin, M.C., Sanchez, M.C., Solomon, J.N., 2006. The pigeon paradox: dependence of global conservation on urban nature. Conserv. Biol. 20, 1814-1816. doi:10.1111/j.1523-1739.2006.00533.x

Eremeeva, N.I., Sushchev, D.V., 2005. Structural changes in the fauna of pollinating insects in urban landscapes. Russ J Ecol 36, 259-265. doi:10.1007/s11184-005-0070-6

Eyre, M.D., Luff, M.L., Woodward, J.C., 2003. Beetles (Coleoptera) on brownfield sites in England: An important conservation resource? Journal of Insect Conservation 7, 223-231. doi:10.1023/B:JICO.0000021020.66549.1e

Fernandez-Juricic, E., 2000. Avifaunal use of wooded streets in an urban landscape. Conservation Biology 14, 513-521. doi:10.1046/j.1523-1739.2000.98600.x

Florencia Carballido, M., Arístide, P., Busch, M., Cittadino, E.A., Gómez Villafañe, I.E., 2011. Are the closed landfills recovered habitats for small rodents? A case study in a riparian site, Buenos Aires, Argentina. Urban Ecosystems 14, 699-710. doi:10.1007/s11252-011-0167-6

Franceschi, E.A., 1996. The ruderal vegetation of Rosario City, Argentina. Landscape and Urban Planning 34, 11-18. doi:10.1016/0169-2046(95)00203-0

Francis, R.A., 2011. Wall ecology: A frontier for urban biodiversity and ecological engineering. Progress in Physical Geography 35, 43-63. doi:10.1177/0309133310385166

Francis, R.A., Hoggart, S.P.G., 2008. Waste not, want not: the need to utilize existing artificial structures for habitat improvement along urban rivers. Restoration Ecology 16, 373-381. doi: 10.1111/j.1526100X.2008.00434.X

Francis, R.A., Hoggart, S.P.G., 2009. Urban river wall habitat and vegetation: observations from the River Thames through central London. Urban Ecosystems 12, 465-485. doi:10.1007/s11252-009-0096-9

Francis, R.A., Hoggart, S.P.G., 2012. The flora of urban river wallscapes. River Res. Applic. 28, 1200-1216. doi:10.1002/rra.1497

Fründ, H.-C., Söntgen, M., Schulte, W., Ruszkowski, B., 1988. Untersuchungen zur Biologie städtischer Böden. 1. Konzeption des Forschungsprojekts Bonn-Bad Godesberg und erste Gesamtergebnisse (Studies on the biology of urban soil. 1. Concept of the research project Bonn-Bad Godesberg and first comprehensive results). Verhandlungen der Gesellschaft für Ökologie 18, 167-174.

Galluzzi, G., Eyzaguirre, P., Negri, V., 2010. Home gardens: neglected hotspots of agro-biodiversity and cultural diversity. Biodivers Conserv 19, 3635-3654. doi:10.1007/s10531-010-9919-5

Gantes, P., Falco, L.B., Coviella, C.E., Caro, A.S., 2014. Plant secondary succession age-related changes in landfills. Urban Ecosystems 17, 1209-1218. doi:10.1007/s11252-014-0366-z

Garcillán, P.P., Rebman, J.P., Casillas, F., 2009. Analysis of the non-native flora of Ensenada, a fast growing city in northwestern Baja California. Urban Ecosystems 12, 449-463. doi:10.1007/s11252-0090091-1

Garden, J.G., McAlpine, C.A., Peterson, A., Jones, D.N., Possingham, H.P., 2006. Review of the ecology of Australian urban fauna: A focus on spatially explicit processes. Austral Ecol 31, 126-148. doi:10.1111/j.1442-9993.2006.01578.x 
Gardiner, M.M., Burkman, C.E., Prajzner, S.P., 2013. The value of urban vacant land to support arthropod biodiversity and ecosystem services. Environmental Entomology 42, 1123-1136. doi:10.1603/EN12275

Gatesire, T., Nsabimana, D., Nyiramana, A., Seburanga, J.L., Mirville, M.O., 2014. Bird diversity and distribution in relation to urban landscape types in Northern Rwanda. The Scientific World Journal 2014, 1-12. doi:10.1155/2014/157824

Geibert, E.H., 1980. Songbird diversity along an urban powerline right-of-way in Rhode-Island. Environmental Management 4, 205-213.

Gilbert, O., 1990. The lichen flora of urban wasteland. Lichenologist 22, 87-101.

Goddard, M.A., Dougill, A.J., Benton, T.G., 2010. Scaling up from gardens: biodiversity conservation in urban environments. Trends Ecol. Evol. (Amst.) 25, 90-98. doi:10.1016/j.tree.2009.07.016

Godefroid, S., Koedam, N., 2007. Urban plant species patterns are highly driven by density and function of built-up areas. Landscape Ecol 22, 1227-1239. doi:10.1007/s10980-007-9102-x

Godefroid, S., Monbaliu, D., Koedam, N., 2007. The role of soil and microclimatic variables in the distribution patterns of urban wasteland flora in Brussels, Belgium. Landscape and Urban Planning 80, 45-55. doi:10.1016/j.landurbplan.2006.06.001

Gong, C., Chen, J., Yu, S., 2013. Biotic homogenization and differentiation of the flora in artificial and nearnatural habitats across urban green spaces. Landscape and Urban Planning 120, 158-169. doi:10.1016/j.landurbplan.2013.08.006

Gruttke, H., 1988. Die Carabidenfauna eines Ruderalbiotops in der Stadtrandzone von Berlin (The Carabid fauna of a ruderal biotope in the urban fringe of Berlin). Verhandlungen der Gesellschaft für Ökologie 18, 233-238.

Guggenheim, E., 1992. Mauervegetation in der Stadt Zürich (Wall vegetation in the city of Zürich). Berichte des Geobotanischen Institutes der Eidgenössischen Technischen Hochschule Stiftung Rübel 16416191.

Guitart, D., Pickering, C., Byrne, J., 2012. Past results and future directions in urban community gardens research. Urban Forestry \& Urban Greening 11, 364-373. http://dx.doi.org/10.1016/j.ufug.2012.06.007

Gupta, S., Narayan, R., 2010. Plant diversity and dry-matter dynamics of peri-urban plant communities in an Indian dry tropical region. Ecol Res 26, 67-78. doi:10.1007/s11284-010-0760-9

Haigh, M.J., 1980. Ruderal communities in English cities. Urban Ecology 4, 329-338. doi:10.1016/03044009(80)90004-2

Hanba, Y.T., Kobayashi, T., Enomoto, T., 2009. Variations in the foliar $\delta 13 \mathrm{C}$ and C3/C4 species richness in the Japanese flora of Poaceae among climates and habitat types under human activity. Ecol Res 25, 213-224. doi:10.1007/s11284-009-0652-z

Hard, G., 2001. Natur in der Stadt (Nature in the city)? Berichte zur deutschen Landeskunde 75, 257-270.

Hashimoto, Y., 2010. Impact of the Single Cutting in Summer on Species Composition, Coverage and Species Richness in Sicyos Angulatus Community in the Alien Species-Rich River through the Urban Area in Japan. Landscape Research Japan Online 3, 32-38. doi:10.5632/jilaonline.3.32

Hayasaka, D., Akasaka, M., Miyauchi, D., Box, E.O., Uchida, T., 2012. Qualitative variation in roadside weed vegetation along an urban-rural road gradient. Flora 207, 126-132. doi:10.1016/j.flora.2011.11.005

Head, L., Muir, P., 2006. Suburban life and the boundaries of nature: resilience and rupture in Australian backyard gardens. Trans Inst Br Geog 31, 505-524. doi:10.1111/j.1475-5661.2006.00228.x

Helden, A.J., Leather, S.R., 2004. Biodiversity on urban roundabouts--Hemiptera, management and the species-area relationship. Basic and Applied Ecology 5, 367-377. doi:10.1016/j.baae.2004.06.004

Hobbs, R.J., Arico, S., Aronson, J., Baron, J., Bridgewater, P., Cramer, V., Epstein, P., Ewel, J., Klink, C., Lugo, A., Norton, D., Ojima, D., Richardson, D., Sanderson, E., Valladares, F., Vila, M., Zamora, R., Zobel, M., 2006. Novel ecosystems: theoretical and management aspects of the new ecological world order. Global Ecol Biogeography 15, 1-7. doi:10.1111/j.1466-822x.2006.00212.x

Hoggart, S.P.G., Francis, R.A., Chadwick, M.A., 2012. Macroinvertebrate richness on flood defence walls of the tidal River Thames. Urban Ecosystems 15, 327-346. doi:10.1007/s11252-011-0221-4

Hruska, K., Dell'Uomo, A., Staffolani, L., Torrisi, M., 2008. Influence of urbanization on riparian and algal species composition in two rivers of central Italy. Ecoscience 15, 121-128. 
Ichinose, T., 2006. Relationship between the ocurrence of birds in winter and wooded streets in a central area of Osaka City, Japan. Landscape Research Japan 69, 537-540. doi:10.5632/jila.69.537

Imai, H., 2013. The liminal nature of alleyways: understanding the alleyway roji as a "Boundary" between past and present. Cities 34, 58-66. doi:10.1016/j.cities.2012.01.008

Instone, L., Sweeney, J., 2014. Dog waste, wasted dogs: the contribution of human-dog relations to the political ecology of Australian urban space. Geographical Research 52, 355-364. doi:10.1111/17455871.12059

Isermann, M., 2007. Diversity of bryophytes in an urban area of NW Germany. Lindbergia 32, 75-81.

Itagawa, S., Katagiri, Y., Ichinose, T., Osawa, S., Ishikawa, M., 2010. Environmental factors influencing the habitat of Orthoptera in the reclaimed land of the harbor area. Landscape Research Japan 73, 431436. doi:10.5632/jila.73.431

Jantunen, J., Saarinen, K., Valtonen, A., Saarnio, S., 2006. Grassland vegetation along roads differing in size and traffic density. Ann Bot Fenn 43, 107-117.

Jim, C.Y., Chen, W.Y., 2008. Pattern and divergence of tree communities in Taipei's main urban green spaces. Landscape and Urban Planning 84, 312-323. doi:10.1016/j.landurbplan.2007.09.001

Jim, C.Y., Chen, W.Y., 2010. Habitat effect on vegetation ecology and occurrence on urban masonry walls. Urban Forestry \& Urban Greening 9, 169-178. doi:10.1016/j.ufug.2010.02.004

Jim, C.Y., Chen, W.Y., 2011. Bioreceptivity of buildings for spontaneous arboreal flora in compact city environment. Urban Forestry \& Urban Greening 10, 19-28. doi:10.1016/j.ufug.2010.11.001

Joger, H.G., 1988. Untersuchungen über die Tierwelt einer Stadtmauer (Studies on the fauna of a city wall). Zoologische Jahrbucher: Abteilung fur Systematik, Okologie und Geographie der Tiere 115, 69-91.

Jorgensen, A., Tylecote, M., 2007. Ambivalent landscapes-wilderness in the urban interstices. Landscape Research 32, 443-462. doi:10.1080/01426390701449802

Junghans, T., 2008. Zur Flora der Hauptbahnhöfe von Mannheim und Heidelberg (Baden-Württemberg) (On the flora of the central train stations of Mannheim and Heidelberg (Badem-Württemberg). Braunschweiger Geobotanische Arbeiten 9, 325-344.

Kadas, G., 2006. Rare invertebrates colonizing green roofs in London. Urban Habitats 4, 66-86.

Kantsa, A., Tscheulin, T., Junker, R.R., Petanidou, T., Kokkini, S., 2013. Urban biodiversity hotspots wait to get discovered: The example of the city of Ioannina, NW Greece. Landscape and Urban Planning 120, 129-137. doi:10.1016/j.landurbplan.2013.08.013

Kaupp, A., Brenneisen, S., Klausnitzer, B., Nagel, P., 2004. Eco-faunistic characteristics of the beetle fauna of vegetated roofs (Insecta: Coleoptera). Entomologische Blätter 100, 47-83.

Kazemi, F., Beecham, S., Gibbs, J., 2011. Streetscape biodiversity and the role of bioretention swales in an Australian urban environment. Landscape and Urban Planning 101, 139-148. doi:10.1016/j.landurbplan.2011.02.006

Kazemi, F., Beecham, S., Gibbs, J., Clay, R., 2009. Factors affecting terrestrial invertebrate diversity in bioretention basins in an Australian urban environment. Landscape and Urban Planning 92, 304313. doi:10.1016/j.landurbplan.2009.05.014

Keniger, L., Gaston, K., Irvine, K., Fuller, R., 2013. What are the benefits of interacting with nature? IJERPH 10, 913-935. doi:10.3390/ijerph10030913

Kim, K.D., 2013. Vegetation dynamics on waste landfills in the Seoul Metropolitan Area. International Journal of Environmental Research 7, 801-806.

Kim, K.D., Lee, E.J., 2005. Soil seed bank of the waste landfills in South Korea. Plant Soil 271, 109-121. doi:10.1007/s11104-004-2159-2

Kim, K.D., Lee, E.J., Cho, K.-H., 2004. The plant community of Nanjido, a representative nonsanitary landfill in South Korea: implications for restoration alternatives. Water, Air, \& Soil Pollution 154, 167-185. doi:10.1023/B:WATE.0000022965.15050.09

Koide, M., Katoh, K., Watanabe, S., 2004. Environmental factors influencing wintering avifauna in urban riparian areas. Landscape Research Japan 67, 573-576. doi:10.5632/jila.67.573

Kondo, S., 1983. On Chironomid midges communities captured by light traps in reservoirs of Nagoya City and suburbs. Applied Entomology and Zoology 18, 504-510.

Kottek, M., Grieser, J., Beck, C., Rudolf, B., Rubel, F., 2006. World map of the Köppen-Geiger climate classification updated. Meteorol. Z. 15, 259-263. doi:10.1127/0941-2948/2006/0130

Kowarik, I., 2011. Novel urban ecosystems, biodiversity, and conservation. Environmental Pollution 159, 1974-1983. doi:10.1016/j.envpol.2011.02.022 
Koyanagi, T., Kusumoto, Y., Yamamoto, S., Takeuchi, K., 2012. Potential roles of small and linear habitat fragments in satoyama landscapes for conservation of grassland plant species. Urban Ecosystems 15, 893-909. doi:10.1007/s11252-012-0253-4

Krigas, N., Kokkini, S., 2004. A survey of the alien vascular flora of the urban and suburban area of Thessaloniki, N Greece. Willdenowia - Annals of the Botanic Garden and Botanical Museum BerlinDahlem 34, 81-99.

Kühn, N., 2006. Intentions for the unintentional: spontaneous vegetation as the basis for innovative planting design in urban areas. Journal of Landscape Architecture 2006, 46-53.

Lachmund, J., 2003. Exploring the city of rubble: botanical fieldwork in bombed cities in Germany after World War II. Osiris 18, 234-254.

Lanikova, D., Lososová, Z., 2009. Rocks and walls: natural versus secondary habitats. Folia Geobot 44, 263280. doi:10.1007/s12224-009-9045-X

Lenzin, H., Kohl, J., Muehlethaler, R., Odiet, M., 2001. Verbreitung, Abundanz und Standorte ausgewählter Neophyten in der Stadt Basel (Schweiz) (Distribution, abundance and location of select neophytes in the city of Basel (Switzerland)). Bauhinia 15, 39-56.

Lenzin, H., Meier-Küpfer, H., Schwegler, S., Baur, B., 2007. Hafen-und Gewerbegebiete als Schwerpunkte pflanzlicher Diversität innerhalb urban-industrieller Ökosysteme (Harbour and business districts as focal points of floral diversity in urban-industrial ecosystems). Naturschutz und Landschaftsplanung 39, 86-93.

Lopez-Moreno, I., Diaz-Betancourt, M., Landa, T., 2003. Social insects in human environments - ants in the city of Coatepec (Veracruz, Mexico). Sociobiology 42, 605-621.

Lososová, Z., Horsák, M., Chytrý, M., Cejka, T., Danihelka, J., Fajmon, K., Hajek, O., Jurickova, L., Kintrova, K., Lanikova, D., Otypkova, Z., Rehorek, V., Tichý, L., 2011. Diversity of Central European urban biota: effects of human-made habitat types on plants and land snails. J Biogeogr 38, 1152-1163. doi:10.1111/j.1365-2699.2011.02475.x

Lossau, J., Winter, K., 2011. The social construction of city nature: exploring temporary uses of open green space in Berlin, in: Endlicher, W. (Ed.), Perspectives in Urban Ecology: Ecosystems and Interactions Between Human. Springer, Berlin, pp. 333-347.

Lussier, S.M., Enser, R.W., Dasilva, S.N., Charpentier, M., 2006. Effects of habitat disturbance from residential development on breeding bird communities in riparian corridors. Environmental Management 38, 504-521. doi:10.1007/s00267-005-0088-3

Luther, D., Hilty, J., Weiss, J., Cornwall, C., Wipf, M., Ballard, G., 2008. Assessing the impact of local habitat variables and landscape context on riparian birds in agricultural, urbanized, and native landscapes. Biodiversity and Conservation 17, 1923-1935. doi:10.1007/s10531-008-9332-5

MacGregor-Fors, I., Hernández Ordoñez, O., Ortega-Álvarez, R., 2012. Urban croaking: diversity and distribution of anurans in a neotropical city. Urban Ecosystems. doi:10.1007/s11252-012-0267-y

Madre, F., Vergnes, A., Machon, N., Clergeau, P., 2014. Green roofs as habitats for wild plant species in urban landscapes: First insights from a large-scale sampling. Landscape and Urban Planning 122, 100-107. doi:10.1016/j.landurbplan.2013.11.012

Maskell, L.C., Bullock, J.M., Smart, S.M., Thompson, K., Hulme, P.E., 2006. The distribution and habitat associations of non-native plant species in urban riparian habitats. J Veg Sci 17, 499-508.

Mason, C.F., Hofmann, T.A., Macdonald, S.M., 2006. The winter bird community of river corridors in eastern England in relation to habitat variables. Ornis Fennica 83, 73-85.

Maurel, N., Salmon, S., Ponge, J.-F., Machon, N., Moret, J., Muratet, A., 2010. Does the invasive species Reynoutria japonica have an impact on soil and flora in urban wastelands? Biol Invasions 12, 17091719. doi:10.1007/s10530-009-9583-4

Maurer, U., Peschel, T., Schmitz, S., 2000. The flora of selected urban land-use types in Berlin and Potsdam with regard to nature conservation in cities. Landscape and Urban Planning 46, 209-215.

McLain, R.J., Hurley, P.T., Emery, M.R., Poe, M.R., 2014. Gathering "wild" food in the city: rethinking the role of foraging in urban ecosystem planning and management. Local Environment 19, 220-240. doi:10.1080/13549839.2013.841659

Meek, C.S., Richardson, D.M., Mucina, L., 2010. A river runs through it: land-use and the composition of vegetation along a riparian corridor in the Cape Floristic Region, South Africa. Biological Conservation 143, 156-164. doi:10.1016/j.biocon.2009.09.021 
Meffert, P.J., Dziock, F., 2012. What determines occurrence of threatened bird species on urban wastelands? Biological Conservation 153, 87-96. doi:10.1016/j.biocon.2012.04.018

Melander, B., Holst, N., Grundy, A.C., Kempenaar, C., Riemens, M.M., Verschwele, A., Hansson, D., 2009. Weed occurrence on pavements in five North European towns. Weed Res 49, 516-525. doi:10.1111/j.1365-3180.2009.00713.x

Menke, S.B., Guénard, B., Sexton, J.O., Weiser, M.D., Dunn, R.R., Silverman, J., 2011. Urban areas may serve as habitat and corridors for dry-adapted, heat tolerant species; an example from ants. Urban Ecosystems 2011, 135-163. doi:10.1007/s11252-010-0150-7

Millard, A., 2010. Cultural aspects of urban biodiversity, in: Müller, N., Werner, P., Kelcey, J.G. (Eds.), Urban Biodiversity and Design. Wiley-Blackwell, Oxford, pp. 56-80.

Miller, J.R., 2005. Biodiversity conservation and the extinction of experience. Trends in Ecology \& Evolution 20, 430-434. doi:10.1016/j.tree.2005.05.013

Morin, E., Bouchard, A., Jutras, P., 1989. Ecological analysis of disturbed riverbanks in the Montréal area of Québec. Environmental Management 13, 215-225. doi:10.1007/BF01868368

Motegi, N., Yanai, S., 2005. A study on the characteristics of bird distribution in rooftop vegetation in Tokyo Ward. Landscape Research Japan 68, 597-600. doi:10.5632/jila.68.597

Muratet, A., Machon, N., Jiguet, F., Moret, J., Porcher, E., 2007. The role of urban structures in the distribution of wasteland flora in the greater paris area, France. Ecosystems 10, 661-671. doi:10.1007/s10021-007-9047-6

Muratet, A., Porcher, E., Devictor, V., Arnal, G., Moret, J., Wright, S., Machon, N., 2008. Evaluation of floristic diversity in urban areas as a basis for habitat management. Appl Veg Sci 11, 451-460. doi: $10.3170 / 2008-7-18530$

Murgui, E., 2009. Influence of urban landscape structure on bird fauna: a case study across seasons in the city of Valencia (Spain). Urban Ecosystems 12, 249-263. doi:10.1007/s11252-009-0092-0

Namba, T., Yabuhara, Y., Yukinari, K., Kurosawa, R., 2010. Changes in the avifauna of the Hokkaido University campus, Sapporo, detected by a long-term census. Ornithol. Sci. 9, 37-48. doi:10.2326/osj.9.37

Nassauer, J.I., 1988. The aesthetics of horticulture: neatness as a form of care. HortScience 23, 973-977.

Nassauer, J.I., 1992. The appearance of ecological systems as a matter of policy. Landscape Ecol 6, 239250. doi:10.1007/BF00129702

Nassauer, J.I., Wang, Z., Dayrell, E., 2009. What will the neighbors think? Cultural norms and ecological design. Landscape and Urban Planning 92, 282-292. doi:10.1016/j.landurbplan.2009.05.010

Nemec, K.T., Allen, C.R., Alai, A., Clements, G., Kessler, A.C., Kinsell, T., Major, A., Stephen, B.J., 2011. Woody invasions of urban trails and the changing face of urban forests in the Great Plains, USA. The American Midland Naturalist 165, 241-256.

Noordijk, J., Raemakers, I.P., Schaffers, A.P., Sýkora, K.V., 2009. Arthropod richness in roadside verges in the Netherlands. Terrestrial Arthropod Reviews 2, 63-76. doi:10.1163/187498309X440085

Nowak, A., Nowak, S., 2006. Anthropogenic habitats can shelter threatened plants, in: Nature Conservation. Springer, pp. 107-115.

Öckinger, E., Dannestam, Å., Smith, H.G., 2009. The importance of fragmentation and habitat quality of urban grasslands for butterfly diversity. Landscape and Urban Planning 93, 31-37. doi:10.1016/j.landurbplan.2009.05.021

Oppermann, F.W., Brandes, D., 1993. The flora of the Oker riverbanks. Braunschweiger Naturkundliche Schriften 4, 381-414.

Pavlik, J., Pavlik, S., 2000. Some relationships between human impact, vegetation, and birds in urban environment. Ekol Bratislava 19, 392-408.

Payne, R., 1978. The flora of walls in south-eastern Essex. Watsonia 12, 41-46.

Peel, M.C., Finlayson, B.L., McMahon, T.A., 2007. Updated world map of the Köppen-Geiger climate classification. Hydrology and Earth System Sciences 11, 1633-1644. doi:10.5194/hess-11-16332007

Pennington, D.N., Blair, R.B., 2011. Habitat selection of breeding riparian birds in an urban environment: untangling the relative importance of biophysical elements and spatial scale. Diversity and Distributions 17, 506-518. doi:10.1111/j.1472-4642.2011.00750.x 
Pennington, D.N., Hansel, J., Blair, R.B., 2008. The conservation value of urban riparian areas for landbirds during spring migration: Land cover, scale, and vegetation effects. Biological Conservation 141, 1235-1248. doi:10.1016/j.biocon.2008.02.021

Pennington, D.N., Hansel, J.R., Gorchov, D.L., 2010. Urbanization and riparian forest woody communities: Diversity, composition, and structure within a metropolitan landscape. Biological Conservation 143, 182-194. doi:10.1016/j.biocon.2009.10.002

Penone, C., Machon, N., Julliard, R., Le Viol, I., 2012. Do railway edges provide functional connectivity for plant communities in an urban context? Biological Conservation 148, 126-133. doi:10.1016/j.biocon.2012.01.041

Pickering, C., Byrne, J., 2013. The benefits of publishing systematic quantitative literature reviews for PhD candidates and other early-career researchers. Higher Education Research and Development 33, 534-548. doi:10.1080/07294360.2013.841651

Poague, K., Johnson, R., Young, L., 2000. Bird use of rural and urban converted railroad rights-of-way in southeast Nebraska. Wildlife Soc B 28, 852-864.

Prach, K., Pyšek, P., 2001. Using spontaneous succession for restoration of human-disturbed habitats: experience from Central Europe. Ecological Engineering 17, 55-62.

Prach, K., Řehounková, K., Lencová, K., Júrová, A., Konvalinková, P., Mudrák, O., Študent, V., Vaněček, Z., Tichý, L., Petř́k, P., Šmilauer, P., Pyšek, P., 2014. Vegetation succession in restoration of disturbed sites in Central Europe: the direction of succession and species richness across 19 seres. Applied Vegetation Science 17, 193-200. doi:10.1111/avsc.12064

Pritchard, A., Morgan, N., 2006. Hotel Babylon? Exploring hotels as liminal sites of transition and transgression. Tourism Management 27, 762-772. doi:10.1016/j.tourman.2005.05.015

Pyšek, A., Pyšek, P., Jarosik, V., Hajek, M., Wild, J., 2003. Diversity of native and alien plant species on rubbish dumps: effects of dump age, environmental factors and toxicity. Diversity and Distributions 9, 177-189.

Pyšek, P., Chocholousková, Z., Pyšek, A., Jarošík, V., Chytrý, M., Tichý, L., 2004. Trends in species diversity and composition of urban vegetation over three decades. J Veg Sci 15, 781-788. doi:10.1111/j.1654-1103.2004.tb02321.x

Rall, E.L., Haase, D., 2011. Creative intervention in a dynamic city: A sustainability assessment of an interim use strategy for brownfields in Leipzig, Germany. Landscape and Urban Planning 100, 189201. doi:10.1016/j.landurbplan.2010.12.004

Ranta, P., Kesulahti, J., Tanskanen, A., Viljanen, V., Virtanen, T., 2014. Roadside and riverside green urban corridors in the city of Vantaa, Finland. Urban Ecosyst 1-14. doi:10.1007/s11252-014-0402-z

Rapoport, E., Raffaele, E., Ghermandi, L., Margutti, L., 1995. Edible weeds: a scarcely used resource. Bulletin of the Ecological Society of America 76, 163-166.

Ray, J., George, J., 2009. Phytosociology of roadside communities to identify ecological potentials of tolerant species. Journal of Ecology and The Natural Environment 1, 184-190.

Rebele, F., 1988. Results of floral surveys of industrial areas in West Berlin. Landschaft und Stadt 20, 4966.

Reis, V.A. dos, Lombardi, J.A., Figueiredo, R.A., 2006. Diversity of vascular plants growing on walls of a Brazilian city. Urban Ecosystems 9, 39-43. doi:10.1007/s11252-006-5528-1

Robinson, S.L., Lundholm, J.T., 2012. Ecosystem services provided by urban spontaneous vegetation. Urban Ecosystems 15, 545-557. doi:10.1007/s11252-012-0225-8

Rouquette, J.R., Dallimer, M., Armsworth, P.R., Gaston, K.J., Maltby, L., Warren, P.H., 2013. Species turnover and geographic distance in an urban river network. Diversity Distrib. 19, 1429-1439. doi:10.1111/ddi.12120

Roy, S., Byrne, J., Pickering, C., 2012. A systematic quantitative review of urban tree benefits, costs, and assessment methods across cities in different climatic zones. Urban Forestry \& Urban Greening 11, 351-363. doi:10.1016/j.ufug.2012.06.006

Rudd, H., Vala, J., Schaefer, V., 2002. Importance of backyard habitat in a comprehensive biodiversity conservation strategy: a connectivity analysis of urban green spaces. Restoration Ecology 10, 368375. doi:10.1046/j.1526-100X.2002.02041.X

Rupprecht, C.D.D., Byrne, J.A., Ueda, H., Lo, A.Y.H., 2015. 'It's real, not fake like a park': residents' perception and use of informal urban green-space in Brisbane, Australia and Sapporo, Japan. Landscape and Urban Planning 143, 205-218. doi:10.1016/j.landurbplan.2015.07.003 
Rupprecht, C.D.D., Byrne, J.A., Lo, A.Y.H., 2015. Memories of vacant lots: How and why residents used informal urban greenspace as children and teenagers in Brisbane, Australia and Sapporo, Japan. Children's Geographies (online first). doi:10.1080/14733285.2015.1048427

Rupprecht, C.D.D., Byrne, J.A., 2015. It's real, not fake like a park: Informal greenspace as antigentrification strategy? Presented at the American Association of Geographers Annual Meeting 2015, Chicago. doi:10.13140/RG.2.1.1508.7204

Rupprecht, C.D.D., Byrne, J.A., 2014a. Informal urban green-space: comparison of quantity and characteristics in Brisbane, Australia and Sapporo, Japan. PloS ONE 9, e99784. doi:10.1371/journal.pone.0099784

Rupprecht, C.D.D., Byrne, J.A., 2014b. Informal urban greenspace: a typology and trilingual systematic review of its role for urban residents and trends in the literature. Urban Forestry \& Urban Greening 13, 597-611. doi:10.1016/j.ufug.2014.09.002

Saarinen, K., Valtonen, A., Jantunen, J., Saarnio, S., 2005. Butterflies and diurnal moths along road verges: does road type affect diversity and abundance? Biological Conservation 123, 403-412. doi:10.1016/j.biocon.2004.12.012

Salvati, L., 2003. Distribution and relative abundance of wintering birds in a Mediterranean urban area: The influence of habitat variables. Biota 4, 91-100.

Sanderson, R.A., 1992. Diversity and evenness of hemiptera communities on naturally vegetated derelict land in Nw England. Ecography 15, 154-160.

Sasaki, Y., Shibata, S., Morimoto, Y., 2006. The prediction and healthiness of plant species structure of coastal vegetation on semi-natural and artificial coasts of the Seto Inland Sea. Journal of the Japanese Society of Revegetation Technology 31, 364-372.

Schadek, U., Strauss, B., Biedermann, R., Kleyer, M., 2008. Plant species richness, vegetation structure and soil resources of urban brownfield sites linked to successional age. Urban Ecosystems 12, 115-126. doi:10.1007/s11252-008-0072-9

Schmidt, K.J., Poppendieck, H.-H., Jensen, K., 2014. Effects of urban structure on plant species richness in a large European city. Urban Ecosyst 17, 427-444. doi:10.1007/s11252-013-0319-y

Schmitz, S., 1998. The flora of the former frontier zone in Germany: investigation of three sites in Berlin. Naturschutz und Landschaftsplanung 30, 52-54.

Shaltout, K.H., EL-Sheikh, M.A., 2002. Vegetation of the urban habitats in the Nile Delta region, Egypt. Urban Ecosystems 6, 205-221.

Shushpannikova, G., 2001. Synanthropic changes in the flora of Syktyvkar. Russ J Ecol 32, 130-134.

Small, E., Sadler, J., 2003. Carabid beetle assemblages on urban derelict sites in Birmingham, UK. Journal of Insect Conservation 6, 233-246.

Small, E., Sadler, J.P., Telfer, M., 2006. Do landscape factors affect brownfield carabid assemblages? Science of The Total Environment 360, 205-222. doi:10.1016/j.scitotenv.2005.08.051

Smith-Adao, L.B., Scheepers, A.C.T., 2007. An assessment of the channel morphological changes in the Lourens River, Western Cape. Water SA 33, 559-570.

Strauss, B., Biedermann, R., 2006. Urban brownfields as temporary habitats: driving forces for the diversity of phytophagous insects. Ecography 29, 928-940. doi:10.1111/j.2006.0906-7590.04716.x

Stylinski, C., Allen, E., 1999. Lack of native species recovery following severe exotic disturbance in southern Californian shrublands. J Appl Ecol 36, 544-554.

Sudnik-Wojcikowska, B., Galera, H., 2005. Floristic differences in some anthropogenic habitats in Warsaw. Ann Bot Fenn 42, 185-193.

Sweeney, B., 2009. Producing liminal space: gender, age and class in northern Ontario's tree planting industry. Gender, Place \& Culture 16, 569-586. doi:10.1080/09663690903148432

Tabata, S., Hieda, T., 1978. A Studay on the Conservation of the Environment in Area around Stream Junction and Basin. Journal of the Japanese Institute of Landscape Architects 42, 18-28.

Tan, M., 2010. Orthoptera of the Vacant Lots in Bedok South. Nature in Singapore 3, 69-81.

Tikhonova, G., Tikhonov, I., Bogomolov, P., Surov, A., 2002. Distribution and species diversity of small mammals on river banks in urban territories. Zool Zh 81, 864-870.

Tommasi, D., Miro, A., Higo, H., Winston, M., 2004. Bee diversity and abundance in an urban setting. Can Entomol 136, 851-869.

Trammell, E.J., Bassett, S., 2012. Impact of urban structure on avian diversity along the Truckee River, USA. Urban Ecosystems 15, 993-1013. doi:10.1007/s11252-012-0251-6 
UN-HABITAT, 2012. State of the world's cities 2012/2013. http://www.unhabitat.org/pmss/listItemDetails.aspx?publicationID=3387

Uno, S., Cotton, J., Philpott, S.M., 2010. Diversity, abundance, and species composition of ants in urban green spaces. Urban Ecosystems 13, 425-441. doi:10.1007/s11252-010-0136-5

Vakhlamova, T., Rusterholz, H.-P., Kanibolotskaya, Y., Baur, B., 2014. Changes in plant diversity along an urban-rural gradient in an expanding city in Kazakhstan, Western Siberia. Landscape and Urban Planning 132, 111-120. doi:10.1016/j.landurbplan.2014.08.014

Venn, S.J., Kotze, D.J., Lassila, T., Niemelä, J.K., 2013. Urban dry meadows provide valuable habitat for granivorous and xerophylic carabid beetles. J Insect Conserv 17, 747-764. doi:10.1007/s10841-0139558-8

Vincent, G., Bergeron, Y., 1985. Weed synecology and dynamics in urban environment. Urban Ecology 9 , 161-175. doi:10.1016/0304-4009(85)90004-X

Wahlbrink, D., Zucchi, H., 1994. Occurrence and settlement of carabid beetles on an urban railway embankment - a contribution to urban ecology. Zoologische Jahrbucher: Abteilung fur Systematik, Okologie und Geographie der Tiere 121, 193-201.

Weber, F., Kowarik, I., Säumel, I., 2014. Herbaceous plants as filters: Immobilization of particulates along urban street corridors. Environmental Pollution 186, 234-240. doi:10.1016/j.envpol.2013.12.011

Weinberger, K., 2013. Home and community gardens in Southeast Asia: potential and opportunities for contributing to nutrition-sensitive food systems. Food Sec. 5, 847-856. doi:10.1007/s12571-0130299-z

Westermann, J.R., von der Lippe, M., Kowarik, I., 2011. Seed traits, landscape and environmental parameters as predictors of species occurrence in fragmented urban railway habitats. Basic and Applied Ecology 12, 29-37. doi:10.1016/j.baae.2010.11.006

White, J., Antos, M., Fitzsimons, J., Palmer, G., 2005. Non-uniform bird assemblages in urban environments: the influence of streetscape vegetation. Landscape and Urban Planning 71, 123-135. doi:10.1016/j.landurbplan.2004.02.006

Whitmore, C., Crouch, T., Slotow, R., 2002. Conservation of biodiversity in urban environments: invertebrates on structurally enhanced road islands. Afr Entomol 10, 113-126.

Whitney, G., 1985. A quantitative analysis of the flora and plant communities of a representative midwestern US town. Urban Ecology 9, 143-160.

Wilkerson, M.S., Wilkerson, M.B., 2010. World Map of the Köppen-Geiger climate classification updated (KMZ-format).

Winter, M., 2013. Changes in the urban flora of the commercial harbor in Bremen over the past 18 years. Master thesis, University of Bremen, Bremen.

Wittig, R., Becker, U., 2010. The spontaneous flora around street trees in cities-A striking example for the worldwide homogenization of the flora of urban habitats. Flora 205, 704-709. doi:10.1016/j.flora.2009.09.001

Wojcik, V.A., McBride, J.R., 2012. Common factors influence bee foraging in urban and wildland landscapes. Urban Ecosystems 15, 581-598. doi:10.1007/s11252-011-0211-6

Yamano, M., Shibaike, H., Ide, M., 2004. Analysis on Relationships between Landscape Structures and Distribution Patterns for Native and Hybrid Dandelions (Taraxacum) in Tsukuba-city, Ibaraki Pref. Landscape Research Japan 67, 587-590. doi:10.5632/jila.67.587

Yamato, M., Asami, K., Takeda, Y., 2004. Phytosociological study of semi-natural grasslands in the Ryukyu Islands. Vegetation science 21, 1-13.

Zapparoli, M., 1997. Centipedes of a wasteland urban area in Rome, Italy (Chilopoda). Entomol. Scand. 51, $121-124$.

Zerbe, S., Choi, I.-K., Kowarik, I., 2004. Characteristics and habitats of non-native plant species in the city of Chonju, southern Korea. Ecol Res 19, 91-98. doi:10.1111/j.1440-1703.2003.00616.x

Zhao, J., Ouyang, Z., Zheng, H., Zhou, W., Wang, X., Xu, W., Ni, Y., 2009. Plant species composition in green spaces within the built-up areas of Beijing, China. Plant Ecol 209, 189-204. doi:10.1007/s11258-009-9675-3

Zhao, S., Da, L., Tang, Z., Fang, H., Song, K., Fang, J., 2006. Ecological consequences of rapid urban expansion: Shanghai, China. Frontiers in Ecology and the Environment 4, 341-346.

Zorenko, T., 2003. Species diversity and distribution of mammals in Riga. Acta Zoologica Lituanica 13, 7886. 
Appendix A - Search terms used in English, Japanese, and German

\begin{tabular}{|c|c|c|}
\hline English & Japanese & German \\
\hline \multicolumn{3}{|l|}{ IGSVariable } \\
\hline ruderal & 荒地 (arechi) & ruderal \\
\hline railway & 鉄道 (tetsudō) & Eisenbahn \\
\hline vacant lot & 空き地 (akichi) & leeres Grundstück \\
\hline abandoned lot & 空き地 (akichi) & verlassenes Grundstück \\
\hline walls & 壁 (kabe) & Mauer, Wall \\
\hline street/ & 道の端 (michi no hashi) & Straßenrand, Straßengraben \\
\hline $\begin{array}{l}\text { road verges } \\
\text { curbside }\end{array}$ & 舗道の縁石 (hodō no enseki) & Straßenrand \\
\hline wasteland & 荒地、荒野 (kōya) & Ödland, Brache \\
\hline brownfield & $\begin{array}{l}\text { 工場跡地 (kōjōatochi), } \\
\text { ブラウンフィールド }\end{array}$ & $\begin{array}{l}\text { Industriebrache, Brache, } \\
\text { Braunfeld }\end{array}$ \\
\hline landfill & 埋立地 (umetatechi) & Deponie, Müllhalde \\
\hline industrial park & 工業団地 (kōgyōdanchi) & Industriepark \\
\hline corridor & 回廊 (kairō) & Korridor, Schneise \\
\hline powerline & 電線 (densen) & $\begin{array}{l}\text { Hochspannungsleitung, } \\
\text { Stromleitung }\end{array}$ \\
\hline riverbank & 川岸 (kawagishi) & Flussufer \\
\hline buildings & 建物 (tatemono) & Gebäude \\
\hline road swales & - & Straßengraben \\
\hline trails, foot paths & 路 (michi) & $\begin{array}{l}\text { Weg, Pfad, Fusspfad, } \\
\text { Trampelpfad }\end{array}$ \\
\hline wilderness & 荒野, 自然 (shizen) & Wildniss \\
\hline $\begin{array}{l}\text { spontaneous } \\
\text { vegetation }\end{array}$ & 自然発生植生 (jihatsutekishokusei) & Spontane vegetation \\
\hline novel ecosystem & 新興生態系 (shinkōseitaikei) & Neue Ökosysteme \\
\hline riparian & 河岸 (kawagishi), 川岸、水辺 (suihen) & Ufer... \\
\hline Biodiversity aspects & & \\
\hline biodiversity & 生物多様性 (seibutsutayōsei) & Biodiversität, Artenvielfalt \\
\hline richness & 種豊富さ (shuhōfusa) & Reichtum \\
\hline composition & 種組成 (shusosei) & Zusammensetzung \\
\hline diversity & 種多様性 (shutayōsei) & Diversität, Vielfalt \\
\hline species & 種類 (shurui) & Spezies \\
\hline urban & 都市 (toshi) & urban, städtisch \\
\hline
\end{tabular}


Appendix B (online suppl. info?) - Author, year, location, IGS type, species group, study area, climate zone, IGS description, species number, human impact, and comments on IGS of all 174 individual research papers

\begin{tabular}{|c|c|c|c|c|c|c|c|c|c|}
\hline First author & Year Country & IGS type & Species grour & Study area & Clima & IGS description & $\begin{array}{l}\text { Species } \\
\text { number }\end{array}$ & $\begin{array}{l}\text { Human impact on } \\
\text { IGS }\end{array}$ & Value and comments regarding IGS \\
\hline $\begin{array}{l}\text { Abd El- } \\
\text { Ghani }\end{array}$ & 2011 Egypt & multi & Vegetation & multi & BWh & Wasteland & 172 & & Flora distinct from other urban habitats \\
\hline $\begin{array}{l}\text { Abd El- } \\
\text { Ghani }\end{array}$ & 2012 Egypt & multi & Vegetation & multi & BWh & $\begin{array}{l}\text { Wasteland, abandoned } \\
\text { fields, railways, } \\
\text { highways, canals }\end{array}$ & na & $\begin{array}{l}\text { Pollution, weeding, } \\
\text { canal design }\end{array}$ & $\begin{array}{l}\text { Species diversity increases with aridity, } \\
\text { soil character changed by anthropogenic } \\
\text { activities }\end{array}$ \\
\hline Angold & $2006 \mathrm{UK}$ & Brownfield & Vegetation & Birmingham & $\mathrm{Cfb}$ & Derelict sites & 378 & & $\begin{array}{l}\text { Dispersal between sites important for } \\
\text { flora, chain of habitats, recommend } \\
\text { delaying redevelopment }\end{array}$ \\
\hline Asami & 1999 Japan & multi & $\begin{array}{l}\text { Imperata } \\
\text { cylindrica }\end{array}$ & Okinawa & $\mathrm{Cfa}$ & $\begin{array}{l}\text { Expressway slope, } \\
\text { airfield }\end{array}$ & $8-24$ & cutting & $\begin{array}{l}\text { Separate seed pool from urban ecosystem, } \\
\text { easily invaded }\end{array}$ \\
\hline Asmus & $\begin{array}{l}2014 \text { New } \\
\text { Zealand }\end{array}$ & multi & Vegetation & multi & $\mathrm{Cfb}$ & $\begin{array}{l}\text { Ruderal \& waste areas, } \\
\text { railways, paving, } \\
\text { walkways, walls, lawns } \\
\text { (var. management } \\
\text { levels) }\end{array}$ & 483 & Management, trampli & $\begin{array}{l}89 \% \text { exotic species, town flora very } \\
\text { homogenous, environmental influence } \\
\text { factors include distance from coast \& size } \\
\text { of central business district }\end{array}$ \\
\hline Bacaro & 2012 Germany & Brownfield & Vegetation & Bremen & $\mathrm{Cfb}$ & $\begin{array}{l}\text { Brownfields on } \\
\text { university campus }\end{array}$ & 60 & Trampling, grazing & $\begin{array}{l}\text { No decay of compositional similarity with } \\
\text { increasing spatial or environmental } \\
\text { distance was found }\end{array}$ \\
\hline Banville & 2012 USA & Waterside & Herpetofauna & Tempe & $\mathrm{BWh}$ & Riparian reach & 2 & $\begin{array}{l}\text { Vegetation removal, } \\
\text { water diversion }\end{array}$ & $\begin{array}{l}\text { Disturbed reach had lowest herpetofauna } \\
\text { abundance and species richness, increased } \\
\text { vegetation structural complexity } \\
\text { recommended }\end{array}$ \\
\hline Bigirimana & 2011 Burundi & multi & $\begin{array}{l}\text { Urban } \\
\text { vegetation }\end{array}$ & Bujumbura & Aw & $\begin{array}{l}\text { Ruderal grasslands, } \\
\text { verges, abandoned } \\
\text { ditches }\end{array}$ & $176-337$ & trampling, grazing, fi & High abundance of introduced species \\
\hline Bornkamm & 1961 Germany & Structural & $\begin{array}{l}\text { Spont. } \\
\text { vegetation }\end{array}$ & Göttingen & $\mathrm{Cfb}$ & $\begin{array}{l}\text { Gravel-based unplanted } \\
\text { roofs }\end{array}$ & $2-20$ & construction & $\begin{array}{l}\text { Variety of plant communities, extreme } \\
\text { wet and dry conditions }\end{array}$ \\
\hline Bornkamm & 2007 Germany & Microsite & $\begin{array}{l}\text { Spon. woody } \\
\text { vegetation }\end{array}$ & Berlin & $\mathrm{Cfb}$ & $\begin{array}{l}\text { Bare experimental plots } \\
\text { over } 38 \text { years }\end{array}$ & $\begin{array}{l}17-28, \\
33\end{array}$ & none & $\begin{array}{l}\text { Alien species rare, results support } \\
\text { spontaneous succession as cheap way to } \\
\text { develop near-natural plant communities } \\
\text { rich in species }\end{array}$ \\
\hline
\end{tabular}


First author Year Country IGS type Species groupStudy area Climate IGS description

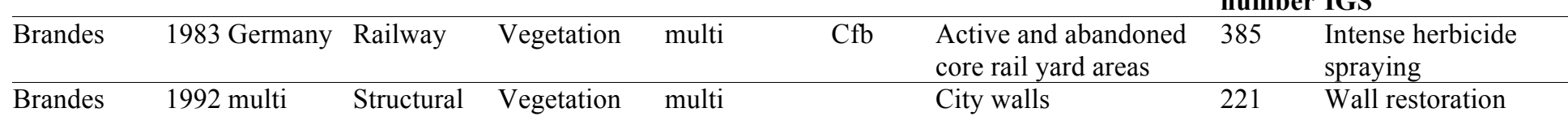

\begin{tabular}{lllll}
\hline Brandes 2001 Germany multi $\quad$ Ruderal plants Lüchow $\quad$ Cfb $\begin{array}{l}\text { Stone and walls, verges, ca. 300 varying } \\
\text { riverbanks, rail tracks, } \\
\text { rail yard, wasteland }\end{array}$ \\
\hline
\end{tabular}

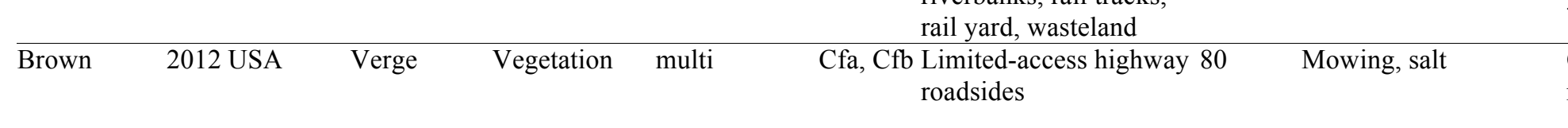

\begin{tabular}{|c|c|c|c|c|c|c|c|c|}
\hline Campbell & $2008 \mathrm{UK}$ & Waterside & Waterbirds & Glasgow & $\mathrm{Cfb}$ & $\begin{array}{l}\text { Riverbank }(0-20 \mathrm{~m} \text { from } \\
\text { bank) }\end{array}$ & 15 & $\begin{array}{l}\text { Presence, food waste, } \\
\text { feeding }\end{array}$ \\
\hline $\begin{array}{l}\text { Carbo- } \\
\text { Ramirez }\end{array}$ & 2011 Mexico & Verge & Birds & Pachuca & Cwb & Road strip corridors & 9 & $\begin{array}{l}\text { Pedestrians, vehicles, } \\
\text { noise, vegetation } \\
\text { cutting }\end{array}$ \\
\hline Castillo & 2003 Argentina & multi & Rodents & Rio Cuarto & Cwa & $\begin{array}{l}\text { Vacant lots, rubbish } \\
\text { dumps, stream banks, } \\
\text { railway banks, vacant } \\
\text { areas }\end{array}$ & 7 & $\begin{array}{l}\text { Food waste, shelter, } \\
\text { control efforts }\end{array}$ \\
\hline Catterall & 2010 Australia & Verge & Birds & Brisbane & Cfa & Suburban road verges & 69 & $\begin{array}{l}\text { Vegetation cutting, } \\
\text { planting, presence }\end{array}$ \\
\hline
\end{tabular}

\begin{tabular}{|c|c|c|c|c|c|c|}
\hline $\begin{array}{l}\text { Celesti- } \\
\text { Grapow }\end{array}$ & 1998 Italy & multi & $\begin{array}{l}\text { Spont. } \\
\text { vegetation }\end{array}$ & multi & $\begin{array}{c}\text { Cfa, Csa Ruins, dumping sites, ca. 50- } \\
\text { industrial sites, road ides } 160\end{array}$ & Intense human use \\
\hline $\begin{array}{l}\text { Celesti- } \\
\text { Grapow }\end{array}$ & 2006 Italy & multi & Vegetation & Rome & $\begin{array}{l}\text { Archeological sites, new 179-324 } \\
\text { development with } \\
\text { wasteland and vacant } \\
\text { lots, historical center } \\
\text { with spon veg, } \\
\text { roadsides, walls }\end{array}$ & Intense human use \\
\hline
\end{tabular}


First author Year Country IGS type Species groupStudy area Climate IGS description

\begin{tabular}{lllllll}
\hline Cervelli & 2013 China & multi & Vegetation & Xi'an & Cwa & $\begin{array}{l}\text { Permeable pavement, } \\
\text { unmanaged soil, walls, } \\
\text { sidewalk, planted beds }\end{array}$ \\
\hline Ceschin & 2010 Italy & Waterside & Vegetation & Rome & Csa & Riverbank
\end{tabular}

\begin{tabular}{|c|c|c|c|c|c|c|c|c|}
\hline Chen & 2014 China & multi & Vegetation & Harbin & Dwa & $\begin{array}{l}\text { Road gap, abandoned } \\
\text { land (soil or gravel) }\end{array}$ & na & $\begin{array}{l}\text { Temperature increase, } \\
\text { land use change, } \\
\text { construction, tramplin }\end{array}$ \\
\hline Chiquet & $2013 \mathrm{UK}$ & Structural & $\begin{array}{l}\text { Vegetation, } \\
\text { birds }\end{array}$ & multi & $\mathrm{Cfb}$ & Vegetated walls & na & Human presence \\
\hline
\end{tabular}

\begin{tabular}{lllllll}
\hline Chmaitelly & 2009 Lebanon multi & Vegetation & Beirut & Csa & Vacant lots, coastal cliffs34-47 limited
\end{tabular}

\begin{tabular}{|c|c|c|c|c|c|c|c|c|}
\hline Christian & 2004 Austria & multi & Protura & Vienna & $\begin{array}{l}\text { Roadside green, bridge, } \\
\text { ruderal sites, waste } \\
\text { disposal site }\end{array}$ & $0-3,5$ & Human-deposited soil & $\begin{array}{l}\text { cultural significance } \\
\text { Anthropogenic habitats bear a poor and } \\
\text { apparently random proturan fauna - yet } \\
\text { contribute one sixth to the overall species } \\
\text { number }\end{array}$ \\
\hline Cilliers & $\begin{array}{r}1998 \text { South } \\
\text { Africa }\end{array}$ & Railway & Vegetation & Potchefstroom Bsk & Railway reserves & 169 & $\begin{array}{l}\text { Soil compaction, } \\
\text { herbicide }\end{array}$ & $\begin{array}{l}\text { Low species number per sample plot in } \\
\text { comparison with natural areas, } \\
\text { management should encourage } \\
\text { successional changes }\end{array}$ \\
\hline Cilliers & $\begin{array}{l}1999 \text { South } \\
\text { a } \quad \text { Africa }\end{array}$ & multi & Vegetation & Potchefstroom Bsk & $\begin{array}{l}\text { Pavements, parking } \\
\text { areas }\end{array}$ & na & $\begin{array}{l}\text { Herbicide, weeding, } \\
\text { mowing }\end{array}$ & $\begin{array}{l}\text { Previously undescribed communities, } \\
\text { conservation not necessarily means } \\
\text { changes in maintenance practices }\end{array}$ \\
\hline Cilliers & $\begin{array}{l}1999 \text { South } \\
\text { b } \quad \text { Africa }\end{array}$ & Lot & Ruderal plant & Potchefstroom Bsk & Vacant lots & 172 & $\begin{array}{l}\text { Disturbed soil (post- } \\
\text { building) lots }\end{array}$ & $\begin{array}{l}\text { Relatively low percentage of introduced } \\
\text { species }(35 \%) \text {, no similarities with ruderal } \\
\text { communities in other continents }\end{array}$ \\
\hline Cilliers & $\begin{array}{r}2000 \text { South } \\
\text { Africa }\end{array}$ & Verge & Vegetation & Potchefstroom Bsk & Road verges & 253 & $\begin{array}{l}\text { Construction, } \\
\text { maintenance }\end{array}$ & $\begin{array}{l}\text { Well-established vegetation, low } \\
\text { percentage of introduced species }(26 \%), \\
\text { higher than similar ruderal sites in the city } \\
\text { (see Cilliers } 1998,1999 \mathrm{a}, 1999 \mathrm{~b})\end{array}$ \\
\hline
\end{tabular}


Species Human impact on

number IGS

Clemens 1984 UK $\quad$ Brownfield Vegetation $\quad$ Sheffield $\quad$ Cfb $\quad$ Derelict demolition sites 83-93,

152

rubble

\section{Value and comments regarding IGS}

Cheap landscaping could increase potential use, diversity and attractiveness could be increased by sowing seed collections from other wasteland sites

\begin{tabular}{|c|c|c|c|c|c|c|c|c|c|}
\hline \multirow{3}{*}{$\begin{array}{l}\text { Colla } \\
\text { Crawford }\end{array}$} & \multirow{3}{*}{$\begin{array}{l}2009 \text { Canada } \\
1979 \text { USA }\end{array}$} & \multirow{3}{*}{$\begin{array}{l}\text { Structural } \\
\text { Brownfield }\end{array}$} & \multirow{3}{*}{$\begin{array}{l}\text { Apidae } \\
\text { Spiders, } \\
\text { arthropods }\end{array}$} & \multirow{3}{*}{$\begin{array}{l}\text { Toronto } \\
\text { Seattle }\end{array}$} & \multirow{3}{*}{$\begin{array}{l}\mathrm{Dfb} \\
\mathrm{Csb}\end{array}$} & \multirow{2}{*}{\multicolumn{2}{|c|}{$\begin{array}{l}\text { Spontaneously vegetated } 54 \\
\text { green roof }\end{array}$}} & \multirow{2}{*}{\multicolumn{2}{|c|}{$\begin{array}{l}\begin{array}{l}\text { None after construction Green roofs can offer habitat for a variety } \\
\text { of bee species }\end{array} \\
\end{array}$}} \\
\hline & & & & & & & & & \\
\hline & & & & & & $\begin{array}{l}\text { Former dumping site } \\
\text { with surface earth fill }\end{array}$ & na & $\begin{array}{l}\text { Construction, limited } \\
\text { afterwards }\end{array}$ & $\begin{array}{l}\text { Low arthropod diversity, absence of low } \\
\text { dispersal ability taxa, spider fauna } \\
\text { dominated by an introduced species }\end{array}$ \\
\hline Crowe & 1979 USA & Lot & $\begin{array}{l}\text { Flowering } \\
\text { plants }\end{array}$ & Chicago & Dfa & Vacant lots & 128 & Mowing & $\begin{array}{l}\text { Diversity increases with age and lot size, } \\
\text { decrease with isolation }\end{array}$ \\
\hline Dallimer & 2012 UK & Waterside & $\begin{array}{l}\text { Vegetation, } \\
\text { birds, } \\
\text { butterflies }\end{array}$ & Sheffield & $\mathrm{Cfb}$ & $\begin{array}{l}\text { Heavily modified } \\
\text { riparian corridors }\end{array}$ & \multicolumn{2}{|c|}{$\begin{array}{l}363,74, \text { Pollution, canalization } \\
21\end{array}$} & $\begin{array}{l}\text { Important part of urban habitat mosaic, } \\
\text { influence of habitat diversity (positive) } \\
\text { and sealed surface (negative) on species } \\
\text { richness }\end{array}$ \\
\hline Dana & 2002 Spain & multi & $\begin{array}{l}\text { Urban } \\
\text { vegetation }\end{array}$ & Almeria & Csa & $\begin{array}{l}\text { Vacant lots, walls, } \\
\text { dumps }\end{array}$ & na & $\begin{array}{l}\text { Complete destruction } \\
\text { of vegetation possible } \\
\text { several times a year }\end{array}$ & $\begin{array}{l}\text { Should be considered for conservation, } \\
\text { contain rare species, balance between } \\
\text { protection and needed disturbance } \\
\text { difficult }\end{array}$ \\
\hline De Neef & $\begin{array}{l}2008 \text { New } \\
\text { Zealand }\end{array}$ & Structural & Vegetation & multi & $\mathrm{Cfb}$ & Walls & 117 & $\begin{array}{l}\text { Frequent spraying and } \\
\text { cleansing }\end{array}$ & $\begin{array}{l}\text { High number of exotic species, numerous } \\
\text { benefits of wall vegetation, great potential } \\
\text { (large area, additional vertical space for } \\
\text { densely developed districts) }\end{array}$ \\
\hline $\begin{array}{l}\text { Dehnen- } \\
\text { Schmutz }\end{array}$ & 2004 Germany & Structural & $\begin{array}{l}\text { Alien plant } \\
\text { species }\end{array}$ & multi & $\mathrm{Cfb}$ & Castle rocks and walls & na & limited & $\begin{array}{l}\text { Number of usable exotic plants show } \\
\text { historical reasons for introduction }\end{array}$ \\
\hline Desjardins & 2014 Canada & Brownfield & Vegetation & Varennes & Dfb & $\begin{array}{l}\text { Former decantation } \\
\text { basin }\end{array}$ & 23 & Pollution & $\begin{array}{l}\text { Rare species excluded, up to } 60 \% \text { of } \\
\text { variance in spont. Plant distribution was } \\
\text { explained by pollutant dispersion pattern }\end{array}$ \\
\hline $\begin{array}{l}\text { Diaz- } \\
\text { Betancourt }\end{array}$ & 1999 multi & multi & Edible weeds & multi & $\mathrm{Csb}$ & $\begin{array}{l}\text { Verges, pathways, } \\
\text { vacant lots }\end{array}$ & $43(\mathrm{Cor}$ & tepec), 32 (Bariloche) & $\begin{array}{l}\text { Significant potential as food source } \\
\text { providing more than } 1 \text { ton per ha of edible } \\
\text { fresh biomass }\end{array}$ \\
\hline Dickman & 1987 UK & multi & $\begin{array}{l}\text { Small } \\
\text { mammals and } \\
\text { plant }\end{array}$ & Oxford & $\mathrm{Cfb}$ & $\begin{array}{l}\text { Minimally managed lor } \\
\text { grass fields }\end{array}$ & $97-58$ & Minimal & $\begin{array}{l}\text { Vegetation more important for small } \\
\text { mammals than urban environment factors }\end{array}$ \\
\hline
\end{tabular}


First author Year Country IGS type Species groupStudy area Climate IGS description

\begin{tabular}{|c|c|c|c|c|c|c|c|}
\hline \multicolumn{8}{|c|}{ mumber Tus } \\
\hline Dingaan & $\begin{array}{r}2013 \text { South } \\
\text { Africa }\end{array}$ & multi & Vegetation & Bloemfontain BSk & $\begin{array}{l}\text { Drainage line } \\
\text { surroundings, fallows, } \\
\text { vacant lots, railway and } \\
\text { road verges }\end{array}$ & na & $\begin{array}{l}\text { Grazing, burning, } \\
\text { mowing }\end{array}$ \\
\hline Do & $\begin{array}{r}2014 \text { South } \\
\text { Korea }\end{array}$ & Brownfield & $\begin{array}{l}\text { Carabid } \\
\text { beetles }\end{array}$ & Busan & $\begin{array}{l}\text { Covered-up former } \\
\text { landfill }\end{array}$ & 15 & $\begin{array}{l}\text { Artificial drainage } \\
\text { facilities }\end{array}$ \\
\hline Eremeeva & 2005 Russia & multi & $\begin{array}{l}\text { Pollinating } \\
\text { insects }\end{array}$ & Kemerovo & Industrial zone & 36,7 & Litter, pollution \\
\hline
\end{tabular}

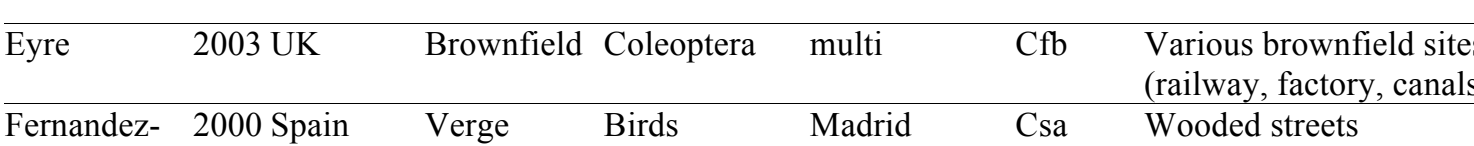

\section{Fernan
Juricic}

Florencia

Carballido

2011 Argentina Brownfield Rodents,

plants

Buenos Aires Cfa Closed landfill

Ruderal

vegetation

Rosario

Cfa

\begin{tabular}{ll}
\hline Franceschi 1996 Arge \\
\\
\hline Francis 2008 UK
\end{tabular}

Vegetation

Waterside Vegetation London

$\mathrm{Cfb}$

(

\begin{tabular}{llllllll}
\hline Francis & 2009 UK & Waterside & Vegetation & London & Cfb & River walls & 20 \\
\hline Francis & 2011 UK & Waterside & Vegetation & London & Cfb & River walls & 90
\end{tabular}

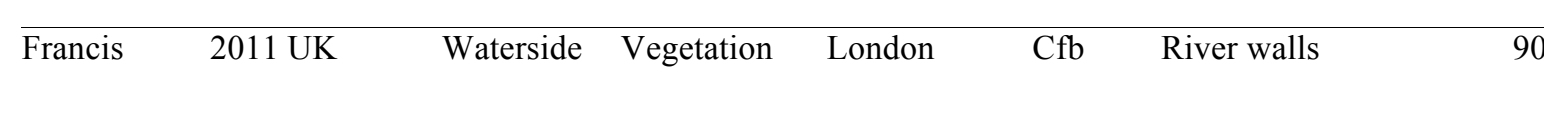

Fründ

1988 Germany multi $\quad \begin{aligned} & \text { Soil biota and Berlin } \\ & \text { vegetation }\end{aligned}$

Closed landfill

Vegetated vacant lots

River walls

Species Human impact on number IGS

Preservation important because vegetation could form dispersal corridors

Landfill provides stable habitat, but drainage facilities critically affect beetles (fall into drainage)

Large areas of urban plots with partly restored vegetation provide sufficient food supply for butterflied and bumblebees, pollution important for bumblebees

Large number of rare species, high conservation value

Vegetation structure and park connection have positive influence

4 Pedestrians, vehicles

6,70 Reduced vegetation dueMostly indigenous species, can play role to landfill legacy

in conservation, vegetation structure factors explain most abundance data

Mowing, burning, No similarity to other vacant lot studies, weeding, rubble, many therophytes, usually one rubbish dominating species per community

Maintenance, choice of Strong influence of substrate material on substrate

habitat potential, brick and boulders preferred to concrete, conservation potential

Maintenance, pollution, Mix of terrestrial and riparian species, choice of substrate surface fractures increase plant diversity, habitat improvement potential

Limited, maintenance, "Mass effect" - flora maintained by pollution, substrate propagule pressure, significantly more choice diversity on bricks than sheet metal, $\begin{array}{ll} & \text { potential for habitat improvement } \\ \text { Trampling (including } & \text { High diversity, wasteland and verges }\end{array}$ $\begin{array}{lll}\text { Wasteland, parking na } & \begin{array}{l}\text { Trampling (including } \\ \text { space, verges, street tree }\end{array} & \begin{array}{l}\text { High diversity, wasteland and verges } \\ \text { more diverse than flower plantings }\end{array}\end{array}$ 


\begin{tabular}{|c|c|c|c|c|c|c|c|c|c|}
\hline & & & & & & & & & \\
\hline Gantes & 2014 Argentina & Brownfield & Vegetation & Buenos Aires & Cfa & Partly active landfills & 48 & $\begin{array}{l}\text { Machinery movement, } \\
\text { maintenance, mowing, } \\
\text { cover material }\end{array}$ & $\begin{array}{l}\text { Exotic species are dominant, natives gain } \\
\text { with age of cells, in oldest cells some } \\
\text { species belong to local climax community }\end{array}$ \\
\hline Garcillán & 2009 Mexico & Lot & $\begin{array}{l}\text { Non-native } \\
\text { vegetation }\end{array}$ & Ensenada & Bsk & Vacant lots & 97 & & $\begin{array}{l}\text { High percentage }(61 \%) \text { of non-natives in } \\
\text { comparison to other vacant lot studies }\end{array}$ \\
\hline Gatesire & 2014 Rwanda & multi & Birds & Musanze & $\mathrm{Cfb}$ & $\begin{array}{l}\text { Riversides, streamsides, } \\
\text { wasteland }\end{array}$ & $\begin{array}{l}35,24 \\
16\end{array}$ & $\begin{array}{l}\text { Human presence, } \\
\text { vehicle noise }\end{array}$ & $\begin{array}{l}\text { Lower diversity than other urban } \\
\text { landscapes, but different microlandscape } \\
\text { types harbor different species }\end{array}$ \\
\hline Geibert & 1980 USA & Powerline & Songbirds & $\begin{array}{l}\text { South } \\
\text { Kingstown }\end{array}$ & $\mathrm{Cfb}$ & Powerline right-of-way & 52 & Infrequent cutting & $\begin{array}{l}\text { High diversity, higher than in neighboring } \\
\text { residential area, vegetation structure } \\
\text { complexity and cover over } 60 \mathrm{~cm} \\
\text { correlated with bird diversity }\end{array}$ \\
\hline Gilbert & $1990 \mathrm{UK}$ & multi & Lichen & multi & $\mathrm{Cfb}$ & $\begin{array}{l}\text { Highly urban, recently } \\
\text { disturbed wasteland }\end{array}$ & 100 & $\begin{array}{l}\text { Rubble, rubbish } \\
\text { dumping, maintenance, } \\
\text { vehicle encroachment, } \\
\text { contractors' camps, } \\
\text { bonfires and children's } \\
\text { play }\end{array}$ & $\begin{array}{l}\text { Higher than expected diversity, rare and } \\
\text { newly discovered species, threatened by } \\
\text { development and economic growth }\end{array}$ \\
\hline Godefroid & 2007 Belgium & multi & Vegetation & Brussels & $\mathrm{Cfb}$ & $\begin{array}{l}\text { Derelict and despoiled } \\
\text { land }\end{array}$ & na & $\begin{array}{l}\text { Former land use, } \\
\text { pollution }\end{array}$ & $\begin{array}{l}\text { Probability of species occurrence related } \\
\text { to land use }\end{array}$ \\
\hline Godefroid & 2007 Belgium & multi & Vegetation & Brussels & $\mathrm{Cfb}$ & $\begin{array}{l}\text { Former industrial area, } \\
\text { demolished house lots }\end{array}$ & 74 & Trampling & $\begin{array}{l}\text { Concrete substrate and walls around a site } \\
\text { lowered diversity, different anthropogenic } \\
\text { substrates have different flora }\end{array}$ \\
\hline Gong & 2013 China & Verge & Vegetation & Shenzhen & Cwa & $\begin{array}{l}\text { Linear corridors along } \\
\text { roads and sidewalks or } \\
\text { island patches }\end{array}$ & 205 & & $\begin{array}{l}\text { Verges similar to residential and } \\
\text { industrial vegetation in native-alien ratio, } \\
\text { alien species widespread }\end{array}$ \\
\hline Gruttke & 1988 Germany & Lot & Carabids & Berlin & $\mathrm{Cfb}$ & Abandoned ruderal area & 68 & & $\begin{array}{l}\text { Building density and use intensity } \\
\text { influence carabid distribution }\end{array}$ \\
\hline Guggenheim & $\begin{array}{l}1992 \text { Switzerlan } \\
\text { d }\end{array}$ & Structural & multi & Zurich & $\mathrm{Cfb}$ & Vegetated walls & $\begin{array}{l}199,51 \\
\text { (moss) }\end{array}$ & $\begin{array}{l}\text { Maintenance, substrate } \\
\text { choice, herbicides }\end{array}$ & $\begin{array}{l}\text { Wall vegetation contributes to urban } \\
\text { diversity and to the visual character of the } \\
\text { city center and thus deserves protection, } \\
\text { human beauty perception plays a role in } \\
\text { conservation }\end{array}$ \\
\hline Gupta & 2010 India & Brownfield & Vegetation & Bulandshahr & Cwa & Brick kiln brownfield & 25 & Brick and ash rubble & $\begin{array}{l}\text { Varying diversity in different seasons, } \\
\text { less diversity due to brick dust stress }\end{array}$ \\
\hline
\end{tabular}


First author Year Country IGS type Species groupStudy area Climate IGS description

\begin{tabular}{lllllllll}
\hline Haigh & 1980 UK & Lot & $\begin{array}{l}\text { Spont. } \\
\text { vegetation }\end{array}$ & Birmingham & Cfb & Weed patches & 61 & \\
\hline Hanba & 2009 Japan & multi & Poaceae & multi & & $\begin{array}{l}\text { Open wasteland, } \\
\text { roadside, empty lots }\end{array}$ & 76 & Gas exhaust \\
\hline Hashimoto & 2010 Japan & Waterside & Vegetation & Osaka & Cfa & Riverbanks and islands & 39 & Cutting
\end{tabular}

\begin{tabular}{lllllllll}
\hline Hayasaka & 2012 Japan & Verge & Vegetation & multi & Cfa & Curbside cracks & na & Mowing, traffic \\
\hline Helden & $2004 \mathrm{UK}$ & Verge & $\begin{array}{l}\text { Hemiptera, } \\
\text { grassland } \\
\text { plants }\end{array}$ & Bracknell & Cfb & $\begin{array}{l}\text { Roundabouts and other } \\
\text { road-enclosed sites }\end{array}$ & 1-17 & Cutting, herbicide \\
& & & & &
\end{tabular}

\begin{tabular}{lllllll}
\hline Hoggart $2012 \mathrm{UK}$ & Waterside & $\begin{array}{l}\text { MacroinvertebLondon } \\
\text { rates }\end{array}$ & $\mathrm{Cfb}$ & Flood defense walls & 37 & Wall design choice \\
\hline
\end{tabular}

\begin{tabular}{|c|c|c|c|c|c|c|c|}
\hline Hruska & 2008 Italy & Waterside & $\begin{array}{l}\text { Vegetation, } \\
\text { algae }\end{array}$ & Ascoli Piceno Cfb & Riparian areas & 53 & Strong human influence \\
\hline Ichinose & 2006 Japan & Verge & Birds & Osaka & Wooded streets & 8 & $\begin{array}{l}\text { Urban matrix (perching } \\
\text { etc.) }\end{array}$ \\
\hline Isermann & 2007 Germany & multi & Bryophytes & Bremen & $\begin{array}{l}\text { University grounds } \\
\text { (grassland and } \\
\text { stonework) }\end{array}$ & 40 & \\
\hline Itagawa & 2010 Japan & multi & Orthoptera & Yokohama & $\begin{array}{l}\text { Wooded streets on } \\
\text { reclaimed land }\end{array}$ & na & \\
\hline Jantunen & 2006 Finland & Verge & Vegetation & multi & Intersections, verges & na & $\begin{array}{l}\text { Road-related effects } \\
\text { (drastic chemical and } \\
\text { physical changes) }\end{array}$ \\
\hline $\mathrm{Jim}$ & 2008 China & Structural & Trees & Hong Kong & Stone retaining walls & 30 & $\begin{array}{l}\text { Wall characteristics, } \\
\text { maintenance }\end{array}$ \\
\hline
\end{tabular}

Value and comments regarding IGS

Urban ruderal communities may comprise consistent and separate plant associations

$\mathrm{C} 3$ and $\mathrm{C} 4$ alien species prefer ruderal habitat compared to the native species Elimination of dominant alien plant has temporary positive effect on native plant richness but causes other alien plant to dominate

Road management practices favor ephemeral annuals and short-lived taxa, arable land weeds dominant

Grassland Hemiptera diversity would be increased with a reduction in the intensity of management, such a reduction in the frequency of mowing

Highest richness on brick walls, lowest richness on concrete walls, influence of algal cover and river flows

ceDifferent levels of anthropogenic disturbance are reflected in the two rivers' ecosystem health

Strong relationship with vegetation cover and $>2$ ha woodlot vicinity

High diversity compared to other urban areas

Vegetation height, tree cover and distance to original land are related to inhabitation

Verges are distinct from semi-natural

grasslands, are species-poor due to young age, over-management and disturbance

but show potential if these conditions change (old, unmanaged verges)

Precious ecological asset, natural-cum-

cultural heritage, threatened by misguided maintenance practice 
First author Year Country IGS type Species groupStudy area Climate IGS description

\begin{tabular}{|c|c|c|c|c|c|c|c|c|c|}
\hline & & & & & & & & & \\
\hline Jim & 2010 China & Structural & Vegetation & Hong Kong & Cwa & Masonry walls & 162 & $\begin{array}{l}\text { Land use, wall } \\
\text { characteristics, } \\
\text { management }\end{array}$ & $\begin{array}{l}\text { Ecological heritage, environmental and } \\
\text { visual amenities, need to be protected } \\
\text { from management }\end{array}$ \\
\hline Jim & 2011 China & Structural & $\begin{array}{l}\text { Spont. } \\
\text { arboreal flora }\end{array}$ & Hong Kong & Cwa & Buildings & 11 & $\begin{array}{l}\text { Building materials, } \\
\text { maintenance }\end{array}$ & $\begin{array}{l}\text { Conservation and biodiversity value, } \\
\text { places of nature-in-city, beneficial win- } \\
\text { win situations possible }\end{array}$ \\
\hline Joger & 1988 Germany & Structural & Fauna & Göttingen & $\mathrm{Cfb}$ & Town wall & 237 & $\begin{array}{l}\text { Wall characteristics, } \\
\text { maintenance }\end{array}$ & $\begin{array}{l}\text { High diversity, may act as substitute for } \\
\text { disappearing natural habitats (cliffs) }\end{array}$ \\
\hline Junghans & 2008 Germany & Railway & Vegetation & multi & $\mathrm{Cfb}$ & Railway stations & 170 & $\begin{array}{l}\text { Maintenance, ongoing } \\
\text { use }\end{array}$ & $\begin{array}{l}\text { High diversity of species, substrate, } \\
\text { structure and processes }\end{array}$ \\
\hline Kadas & $2006 \mathrm{UK}$ & multi & Invertebrates & London & $\mathrm{Cfb}$ & Roofs, brownfields & ca. 210 & Substrate choice & $\begin{array}{l}\text { High diversity and large future potential, } \\
\text { rare species }\end{array}$ \\
\hline Kantsa & 2013 Greece & multi & Vegetation & Ioannina & Csa & $\begin{array}{l}\text { Old stonewall, rubble, } \\
\text { vacant lots, building } \\
\text { walls, fortress wall. } \\
\text { Microsites }\end{array}$ & 278 & & $\begin{array}{l}\text { Plants of conservation interest present, } \\
\text { wildlife refuge character }\end{array}$ \\
\hline Kaupp & $\begin{array}{l}2004 \text { Switzerlan } \\
\text { d }\end{array}$ & Structural & Beetles & Basel & $\mathrm{Cfb}$ & Vegetated roofs & 183 & Design choices & $\begin{array}{l}\text { High diversity, function as stepping stone } \\
\text { and natural habitat substitute }\end{array}$ \\
\hline Kazemi & 2009 Australia & Verge & $\begin{array}{l}\text { Terrestrial } \\
\text { invertebrates }\end{array}$ & Melbourne & $\mathrm{Cfb}$ & Lawn-type street verges & na & Mowing & $\begin{array}{l}\text { Monoculture lawn with intense } \\
\text { management and low biodiversity }\end{array}$ \\
\hline Kazemi & 2011 Australia & Verge & Invertebrates & Melbourne & $\mathrm{Cfb}$ & Lawn-type street verges & na & Mowing & $\begin{array}{l}\text { Comparatively low diversity, negative } \\
\text { impact of missing flowering plants }\end{array}$ \\
\hline Kim & $\begin{array}{r}2004 \text { South } \\
\text { Korea }\end{array}$ & Brownfield & Vegetation & Seoul & Dwa & $\begin{array}{l}\text { Closed nonsanitary } \\
\text { landfill }\end{array}$ & 255 & Very limited & $\begin{array}{l}\text { Possible to support succession to typical } \\
\text { forests, comparatively high number of } \\
\text { exotics }\end{array}$ \\
\hline Kim & $\begin{array}{r}2005 \text { South } \\
\text { Korea }\end{array}$ & Brownfield & Vegetation & Seoul & Dwa & Closed landfills & $41-141$ & Management & $\begin{array}{l}\text { Soil seed bank important, age related to } \\
\text { diversity }\end{array}$ \\
\hline Kim & $\begin{array}{r}2013 \text { South } \\
\text { Korea }\end{array}$ & Brownfield & $\begin{array}{l}\text { Vascular } \\
\text { plants }\end{array}$ & multi & $\begin{array}{l}\text { Cwa, } \\
\text { Dwa }\end{array}$ & $\begin{array}{l}\text { Waste landfill with } \\
\text { natural vegetation } \\
\text { recovery }\end{array}$ & 275 & $\begin{array}{l}\text { Fill materials, soil } \\
\text { compaction, pollution }\end{array}$ & $\begin{array}{l}\text { Succession is a viable option for } \\
\text { restoration unless no nearby propagule } \\
\text { source is present }\end{array}$ \\
\hline Koide & 2004 Japan & Waterside & Birds & multi & Cfa & Riparian areas & 42 & River modifications & $\begin{array}{l}\text { Areas serve variety of bird species } \\
\text { groups; influence of slope, artificial } \\
\text { structures and vegetation }\end{array}$ \\
\hline Kondo & 1983 Japan & Waterside & Chironomids & Nagoya & Cfa & Water reservoirs & 34 & $\begin{array}{l}\text { Reservoir design, } \\
\text { maintenance }\end{array}$ & $\begin{array}{l}\text { Difference in urban and suburban sites, } \\
\text { influence of water quality, vegetation, } \\
\text { reservoir structure }\end{array}$ \\
\hline
\end{tabular}


First author Year Country IGS type Species groupStudy area Climate IGS description

\begin{tabular}{|c|c|c|c|c|c|c|c|c|c|}
\hline & & & & & & & & & \\
\hline Koyanagi & 2012 Japan & Verge & Vegetation & Tsukuba & $\mathrm{Cfa}$ & $\begin{array}{l}\text { Linear roadside } \\
\text { vegetation }\end{array}$ & 285 & Mowing & $\begin{array}{l}\text { May have functioned as habitats under } \\
\text { regular mowing, can serve as key } \\
\text { reservoirs for recovery }\end{array}$ \\
\hline Krigas & 2004 Greece & multi & $\begin{array}{l}\text { Alien vascula } \\
\text { plants }\end{array}$ & Thessaloniki & $\mathrm{Cfa}$ & $\begin{array}{l}\text { Archaeological sites, } \\
\text { microsites, walls, } \\
\text { fallows }\end{array}$ & na & & $\begin{array}{l}\text { Non-native species not discovered before } \\
\text { found }\end{array}$ \\
\hline Lanikova & 2009 Czech R. & Structural & Vegetation & multi & $\mathrm{Cfb}, \mathrm{D}$ & Wall tops, verticals & 358 & $\begin{array}{l}3 \text { Substrate choice, air } \\
\text { pollution }\end{array}$ & $\begin{array}{l}\text { High diversity, nutrient and moisture-rich, } \\
\text { mostly common species }\end{array}$ \\
\hline Lenzin & $\begin{array}{l}2001 \text { Switzerlar } \\
\text { d }\end{array}$ & multi & Neophytes & Basel & $\mathrm{Cfb}$ & Verges, roofs, cracks & na & $\begin{array}{l}\text { Urban structure, } \\
\text { maintenance, pollution }\end{array}$ & $\begin{array}{l}\text { Some neophytes resistant to urban } \\
\text { disturbance, but outcompeted by natives } \\
\text { in other places }\end{array}$ \\
\hline Lenzin & $\begin{array}{l}2007 \text { Switzerla1 } \\
\text { d }\end{array}$ & Brownfield & Vegetation & Birsfelden & $\mathrm{Cfb}$ & Industrial area, harbor & 230 & $\begin{array}{l}\text { Maintenance, former } \\
\text { use, (absent) } \\
\text { disturbance }\end{array}$ & $\begin{array}{l}\text { High conservation value, absence of } \\
\text { anthropogenic disturbance causes } \\
\text { problems }\end{array}$ \\
\hline Lososova & 2011 multi & multi & $\begin{array}{l}\text { Vegetation } \\
\text { and snails }\end{array}$ & multi & multi & $\begin{array}{l}\text { Successional sites } \\
\text { (construction, } \\
\text { abandoned) }\end{array}$ & 632 , & 5 (plants), 40, 73 (snails) & $\begin{array}{l}\text { High diversity esp. in mid-successional } \\
\text { sites, high conservation value, endangered } \\
\text { by urbanization }\end{array}$ \\
\hline Lussier & 2006 USA & Waterside & Birds & multi & Cfa, C & $\begin{array}{l}\text { Riparian surrounded by } \\
\text { industrial, infrastructure }\end{array}$ & na & Infrastructure, land use & $\begin{array}{l}\text { Infrastructure and residential areas have } \\
\text { most influence, benefit tolerant species }\end{array}$ \\
\hline Luther & 2008 USA & Waterside & Birds & multi & $\mathrm{Csb}$ & Urban riparian areas & na & $\begin{array}{l}\text { Development, } \\
\text { management }\end{array}$ & $\begin{array}{l}\text { Main factors influencing diversity are tree } \\
\text { cover percent and shrub species richness }\end{array}$ \\
\hline $\begin{array}{l}\text { MacGregor- } \\
\text { Fors }\end{array}$ & 2012 Mexico & multi & Anurans & Morelia & Cwb & $\begin{array}{l}\text { Abandoned lots, small } \\
\text { urban waterway }\end{array}$ & 1 & Pollution & $\begin{array}{l}\text { Abandoned lots have highest abundance, } \\
\text { offer better breeding conditions than } \\
\text { polluted waterways }\end{array}$ \\
\hline Madre & 2014 France & Structural & Wild plants & multi & $\mathrm{Cfb}$ & $\begin{array}{l}\text { Green roofs } \\
\text { spontaneously colonized }\end{array}$ & 176 & $\begin{array}{l}\text { Maintenance, substrate } \\
\text { depth }\end{array}$ & $\begin{array}{l}\text { Provide habitat for high number of native } \\
\text { plants, "wild roof" as potential rooftop } \\
\text { model }\end{array}$ \\
\hline Maskell & $2006 \mathrm{UK}$ & Waterside & Vegetation & $\begin{array}{l}\text { West } \\
\text { Midlands }\end{array}$ & $\mathrm{Cfb}$ & Urban riparian areas & 249 & $\begin{array}{l}\text { Channelization, } \\
\text { pollution }\end{array}$ & $\begin{array}{l}\text { Diversity key influence is dominance by } \\
\text { invasive species (regardless of nativeness) }\end{array}$ \\
\hline Mason & $2006 \mathrm{UK}$ & Waterside & Birds & multi & $\mathrm{Cfb}$ & Urban riparian areas & na & Habitat modification & $\begin{array}{l}\text { Urban areas have higher species richness } \\
\text { than rural areas }\end{array}$ \\
\hline Maurel & 2010 France & multi & Vegetation & Paris & $\mathrm{Cfb}$ & $\begin{array}{l}\text { Vacant urban land, } \\
\text { unused spaces, } \\
\text { transportation-related }\end{array}$ & 84 & & $\begin{array}{l}\text { R. japonica negatively influences other } \\
\text { species, but covers not more than } 4 \% \text { per } \\
\text { site }\end{array}$ \\
\hline Maurer & 2000 Germany & multi & $\begin{array}{l}\text { Vascular } \\
\text { plants }\end{array}$ & Berlin & $\mathrm{Cfb}$ & $\begin{array}{l}\text { Former inner-German } \\
\text { border area }\end{array}$ & 249 & $\begin{array}{l}\text { Intense herbicide } \\
\text { spraying }\end{array}$ & $\begin{array}{l}\text { Area provides rare open space habitat for } \\
\text { wild plants within Berlin }\end{array}$ \\
\hline
\end{tabular}




\begin{tabular}{|c|c|c|c|c|c|c|c|c|c|}
\hline & & & & & & & & & \\
\hline Meek & $\begin{array}{r}2010 \text { South } \\
\text { Africa }\end{array}$ & Waterside & Vegetation & multi & Csa, & Urban riparian areas & na & Land use regime & $\begin{array}{l}\text { Urban areas have higher species richness, } \\
\text { alien species can provide ecosystem } \\
\text { services }\end{array}$ \\
\hline Meffert & 2012 Germany & multi & Birds & Berlin & $\mathrm{Cfb}$ & $\begin{array}{l}\text { Brownfields, switching } \\
\text { yard, other }\end{array}$ & 50 & & $\begin{array}{l}\text { Value for endangered species, no impact } \\
\text { of human and dogs, greenspace design } \\
\text { implications }\end{array}$ \\
\hline Melander & 2009 Denmark & Verge & Weeds & multi & $\mathrm{Cfb}$ & $\begin{array}{l}\text { Edges and center of } \\
\text { pavement }\end{array}$ & 86 & $\begin{array}{l}\text { Use/non-use of } \\
\text { glyphosate }\end{array}$ & $\begin{array}{l}\text { Increase of weeds without herbicide, but } \\
\text { not very pronounced }\end{array}$ \\
\hline Menke & 2011 USA & multi & Ants & Raleigh & $\mathrm{Cfa}$ & Industrial areas & 21 & $\begin{array}{l}\text { Disturbance, } \\
\text { impervious surface }\end{array}$ & $\begin{array}{l}\text { Lower species richness than any other } \\
\text { land use type }\end{array}$ \\
\hline Morin & 1989 Canada & Waterside & Vegetation & Montreal & Dfb & Disturbed river banks & 156 & $\begin{array}{l}\text { Disturbance, substrate } \\
\text { choice }\end{array}$ & $\begin{array}{l}\text { Large number of ruderal species, soil } \\
\text { texture and topography strongest } \\
\text { influence }\end{array}$ \\
\hline Motegi & 2005 Japan & Structural & Birds & Tokyo & $\mathrm{Cfa}$ & Roof tops & 12 & Vegetation choice & $\begin{array}{l}\text { Relatively high diversity, tall trees } \\
\text { recommended to attract tree-reliant } \\
\text { species }\end{array}$ \\
\hline Muratet & 2007 France & multi & Vegetation & $\begin{array}{l}\text { Hauts-de- } \\
\text { Seine }\end{array}$ & $\mathrm{Cfb}$ & $\begin{array}{l}\text { Areas with abandoned } \\
\text { vegetation management }\end{array}$ & 365 & Management & $\begin{array}{l}\text { Wasteland has highest species richness of } \\
\text { all habitat types, } 20 \% \text { naturalized species }\end{array}$ \\
\hline Muratet & 2008 France & multi & Vegetation & $\begin{array}{l}\text { Hauts-de- } \\
\text { Seine }\end{array}$ & $\mathrm{Cfb}$ & $\begin{array}{l}\text { Wasteland, walls, } \\
\text { verges, railway }\end{array}$ & na & $\begin{array}{l}\text { Management, substrate } \\
\text { buildings }\end{array}$ & $\begin{array}{l}\text { Highest floristic interest index habitats } \\
\text { semi-natural, dwellings exhibits neg. } \\
\text { influence }\end{array}$ \\
\hline Murgui & 2009 Spain & Brownfield & Birds & Valencia & Csa & Derelict land & na & Built-up land cover & $\begin{array}{l}\text { Positive influence of habitat diversity, } \\
\text { negative influence of built-up habitat }\end{array}$ \\
\hline Namba & 2010 Japan & multi & Birds & Sapporo & $\mathrm{Dfb}$ & Verges, vacant areas & na & $\begin{array}{l}\text { Feeding, vegetation } \\
\text { management }\end{array}$ & $\begin{array}{l}\text { Population decline due to intensified } \\
\text { vegetation management }\end{array}$ \\
\hline Nemec & 2011 USA & Railway & Woody plants & Lincoln & Dfa & $\begin{array}{l}\text { Urban trails along (e.g.) } \\
\text { abandoned railway }\end{array}$ & 19 & Mowing & $\begin{array}{l}\text { Habitat value for native species may } \\
\text { depend on intensive management }\end{array}$ \\
\hline Noordijk & $\begin{array}{l}2009 \text { Netherlan } \\
\text { ds }\end{array}$ & Verge & Arthropods & multi & $\mathrm{Cfb}$ & Road verges & 638 & Maintenance & $\begin{array}{l}\text { High number of indigenous species, high } \\
\text { overall species number, important for } \\
\text { conservation }\end{array}$ \\
\hline Nowak & 2006 Poland & multi & Sozophytes & multi & $\mathrm{Cfb}$ & $\begin{array}{l}\text { Brownfields, rail and } \\
\text { road verges, walls, } \\
\text { industrial areas }\end{array}$ & na & $\begin{array}{l}\text { Disturbance, soil } \\
\text { transformation }\end{array}$ & $\begin{array}{l}\text { Conservation value of strongly } \\
\text { transformed habitats pose conservation } \\
\text { attitude challenge }\end{array}$ \\
\hline Öckinger & 2009 Sweden & multi & Butterflies & Malmö & $\mathrm{Cfb}$ & $\begin{array}{l}\text { Ruderal, industrial or } \\
\text { built-up areas }\end{array}$ & na & & $\begin{array}{l}\text { Ruderal area has highest species richness } \\
\text { and density, high conservation value }\end{array}$ \\
\hline
\end{tabular}




\section{First author Year Country IGS type}

\begin{tabular}{|c|c|c|c|c|c|c|c|c|}
\hline \multirow[b]{2}{*}{ Oppermann } & \multirow[b]{2}{*}{1993 Germany } & \multirow[b]{2}{*}{ Waterside } & \multirow[b]{2}{*}{$\begin{array}{l}\text { Vascular } \\
\text { plants }\end{array}$} & \multirow[b]{2}{*}{$\mathrm{Cfb}$} & \multirow[b]{2}{*}{ Urban riparian areas } & \multicolumn{3}{|c|}{ number IGS } \\
\hline & & & & & & na & Canalization & $\begin{array}{l}\text { Canalized areas less diverse than un-built } \\
\text { ones, many neophytes but little use of } \\
\text { river as vector }\end{array}$ \\
\hline Pavlik & 2000 Slovakia & multi & $\begin{array}{l}\text { Woody plants, Zvolen } \\
\text { birds }\end{array}$ & $\mathrm{Dfb}$ & $\begin{array}{l}\text { Spontaneous woody } \\
\text { vegetation areas }\end{array}$ & $\begin{array}{l}37 \text { (wp), } \\
50 \\
\text { (birds) }\end{array}$ & $\begin{array}{l}\text { Disturbance, } \\
\text { pedestrians, noise }\end{array}$ & $\begin{array}{l}\text { Spontaneous woody vegetation plots had } \\
\text { higher bird diversity, plot size important } \\
\text { for plants and birds }\end{array}$ \\
\hline Payne & $1978 \mathrm{UK}$ & Structural & Vegetation & $\mathrm{Cfb}$ & $\begin{array}{l}\text { Garden, churchyard, } \\
\text { railway, building, } \\
\text { retaining walls }\end{array}$ & 286 & Disturbance, pollution & $\begin{array}{l}29 \% \text { of probable horticultural origin, } \\
\text { derelict railway walls have higher variety }\end{array}$ \\
\hline Pennington & 2008 USA & Waterside & Cincinnati & Cfa & $\begin{array}{l}\text { Riparian edges in } \\
\text { urbanizing area }\end{array}$ & 102 & Built-up area & $\begin{array}{l}\text { Tree cover, native vegetation and building } \\
\text { area influence opposite for native and } \\
\text { non-native species }\end{array}$ \\
\hline Pennington & 2010 USA & Waterside & Woody plants Cincinnati & Cfa & $\begin{array}{l}\text { Riparian edges in } \\
\text { urbanizing area }\end{array}$ & 103 & $\begin{array}{l}\text { Development, altered } \\
\text { hydrology }\end{array}$ & $\begin{array}{l}\text { Native species decrease, non-native } \\
\text { increase with urbanization, some natives } \\
\text { tolerant }\end{array}$ \\
\hline Pennington & 2011 USA & Waterside & Breeding birdsCincinnati & Cfa & $\begin{array}{l}\text { Riparian edges in } \\
\text { urbanizing area }\end{array}$ & 68 & & $\begin{array}{l}\text { Habitat selection factors operate on both } \\
\text { proximate and broader spatial scales }\end{array}$ \\
\hline Penone & 2012 France & Railway & Vegetation & $\mathrm{Cfb}$ & Railway verges & 186 & Herbicide, mowing & $\begin{array}{l}\text { Railway edges function as corridors for } \\
\text { common grassland plants but provide no } \\
\text { bonus to invasive species }\end{array}$ \\
\hline Poague & 2000 USA & Railway & Lincoln & Dfa & Abandoned railroad & na & & $\begin{array}{l}\text { Seasonal fluctuations of species richness } \\
\text { between urban/rural areas }\end{array}$ \\
\hline Prach & 2001 Czech R. & multi & Vegetation & $\mathrm{Cfb}$ & Ruderal urban sites & na & & $\begin{array}{l}\text { Spontaneous succession can be relied } \\
\text { upon for restoration projects, cheap }\end{array}$ \\
\hline Prach & 2014 Czech R. & multi & Vegetation & & $\begin{array}{l}\text { Road verges, ruderal } \\
\text { urban sites, abandoned } \\
\text { fields }\end{array}$ & na & Construction & $\begin{array}{l}\text { Sere identify was not sign., sere } \\
\text { vegetation formed continuum along } \\
\text { moisture gradient and by successional } \\
\text { age, spontaneous succession mostly } \\
\text { results in woodland and is ecologically } \\
\text { suitable restoration option }\end{array}$ \\
\hline Pysek & 2003 Czech R. & Brownfield & Vegetation & $\mathrm{Cfb}$, & Rubbish dumps & 588 & $\begin{array}{l}\text { Disturbance, toxic } \\
\text { waste }\end{array}$ & $\begin{array}{l}\text { Dump area, human density in region and } \\
\text { altitude positively influence species } \\
\text { numbers }\end{array}$ \\
\hline Pysek & 2004 Czech R. & multi & $\begin{array}{l}\text { Synanthropic Plzen } \\
\text { vegetation }\end{array}$ & $\mathrm{Cfb}$ & Ruderal urban habitats & na & $\begin{array}{l}\text { Change in construction } \\
\text { practice, winter salt us }\end{array}$ & $\begin{array}{l}\text { Decrease in archaeophyte species richness } \\
\text { and diversity from } 1960 \text { s to } 1990 \text { s, }\end{array}$ \\
\hline
\end{tabular}


First author Year Country IGS type Species groupStudy area Climate IGS description

\begin{tabular}{|c|c|c|c|c|c|c|c|c|c|}
\hline \multirow[b]{2}{*}{ Ranta } & \multirow[b]{2}{*}{2014 Finland } & \multirow[b]{2}{*}{ multi } & \multirow[b]{2}{*}{ Vegetation } & \multirow[b]{2}{*}{ Vantaa } & \multirow[b]{2}{*}{$\mathrm{Dfb}$} & \multirow[b]{2}{*}{$\begin{array}{l}\text { Road and railway } \\
\text { corridors }\end{array}$} & \multicolumn{2}{|c|}{ number IGS } & \multirow[b]{2}{*}{$\begin{array}{l}\text { Corridors cover only } 2.7 \% \text { of city but } \\
\text { hold } 76.3 \% \text { of flora, CR-strategists } \\
\text { prevail, corridors resilient to disturbance }\end{array}$} \\
\hline & & & & & & & 484 & Maintenance & \\
\hline Rapoport & 1995 Argentina & Lot & Edible weeds & Bariloche & $\mathrm{Csb}$ & Disturbed suburban lots & 24 & $\begin{array}{l}\text { Cultural preferences for } \\
\text { food }\end{array}$ & $\begin{array}{l}\text { Edible weeds can provide considerable } \\
\text { food source, should be used to } \\
\text { complement agriculture }\end{array}$ \\
\hline Ray & 2009 India & Verge & Vegetation & multi & Am, As & Roadside areas & 73 & $\begin{array}{l}\text { Pollution, trampling, } \\
\text { vehicle crushing }\end{array}$ & $\begin{array}{l}\text { Urban areas have higher species richness } \\
\text { than rural areas, more exotics }\end{array}$ \\
\hline Rebele & 1988 Germany & Brownfield & Vegetation & Berlin & $\mathrm{Cfb}$ & $\begin{array}{l}\text { Brownfields and } \\
\text { industrial areas }\end{array}$ & 596 & $\begin{array}{l}\text { Use (industrial, kids), } \\
\text { pollution }\end{array}$ & $\begin{array}{l}\text { Decrease of derelict areas leads to } \\
\text { dwindling wild flora habitats }\end{array}$ \\
\hline Reis & 2006 Brazil & Structural & $\begin{array}{l}\text { Vascular } \\
\text { plants }\end{array}$ & Jundiai & Cfa & Urban walls & 28 & & $\begin{array}{l}\text { Most species grow better on base of wall, } \\
\text { less diversity than in Europe }\end{array}$ \\
\hline Robinson & 2012 Canada & Brownfield & $\begin{array}{l}\text { Vegetation, } \\
\text { invertebrates }\end{array}$ & Halifax & $\mathrm{Dfb}$ & $\begin{array}{l}\text { Urban spontaneous } \\
\text { vegetation sites }\end{array}$ & na & & $\begin{array}{l}\text { Higher plant species diversity, } \\
\text { invertebrate abundance and taxonomic } \\
\text { diversity than lawns and forest }\end{array}$ \\
\hline Rouquette & 2013 UK & Waterside & multi & Sheffield & $\mathrm{Cfb}$ & Don river banks & na & $\begin{array}{l}\text { Legacy of } \\
\text { industrialization, } \\
\text { urbanization, mining, } \\
\text { modification }\end{array}$ & $\begin{array}{l}\text { River banks provide habitat to bird, plant, } \\
\text { butterfly and macroinvertebrate species, } \\
\text { benefit from river connectivity }\end{array}$ \\
\hline Saarinen & 2005 Finland & Verge & $\begin{array}{l}\text { Butterflies an } \\
\text { moths }\end{array}$ & dmulti & Dfb & Urban roadsides & 75 & $\begin{array}{l}\text { Road kill, pollution, } \\
\text { mowing }\end{array}$ & $\begin{array}{l}\text { Important reserve for some species, } \\
\text { diversity similar in different road verge } \\
\text { types }\end{array}$ \\
\hline Salvati & 2003 Italy & multi & Birds & Rome & Csa & $\begin{array}{l}\text { Ruderal areas, verges, } \\
\text { factories }\end{array}$ & na & Development & $\begin{array}{l}\text { Relict areas form basis of rich species } \\
\text { composition, but threatened by } \\
\text { development }\end{array}$ \\
\hline Sanderson & $1992 \mathrm{UK}$ & Brownfield & $\begin{array}{l}\text { Hemiptera, } \\
\text { Vegetation }\end{array}$ & multi & $\mathrm{Cfb}$ & Derelict sites & 149,153 & & $\begin{array}{l}\text { Rare plant species important in } \\
\text { determining rare Hemiptera species } \\
\text { presence }\end{array}$ \\
\hline Sasaki & 2006 Japan & Waterside & Vegetation & multi & Cfa & Artificial coast & na & & $\begin{array}{l}\text { Artificial coasts are colonized by plants } \\
\text { with floating seeds but not by those } \\
\text { without }\end{array}$ \\
\hline Schadek & 2008 Germany & Brownfield & Vegetation & multi & $\mathrm{Cfb}$ & $\begin{array}{l}\text { Derelict industrial, } \\
\text { abandoned railroad, new } \\
\text { land fills }\end{array}$ & 213 & $\begin{array}{l}\text { Soil alteration (rubble, } \\
\text { dog droppings) }\end{array}$ & $\begin{array}{l}\text { High plant species richness possibly } \\
\text { achieved by strong disturbances every } 5 \\
\text { years }\end{array}$ \\
\hline Schmidt & 2014 Germany & multi & $\begin{array}{l}\text { Vascular } \\
\text { plants }\end{array}$ & Hamburg & $\mathrm{Cfb}$ & $\begin{array}{l}\text { Port, industrial sites, } \\
\text { railway system, traffic }\end{array}$ & na & Urban redevelopment & $\begin{array}{l}\text { Diversity similar between urbanization } \\
\text { zones, high number of species }\end{array}$ \\
\hline
\end{tabular}




\begin{tabular}{|c|c|c|c|c|c|c|c|c|c|}
\hline & & & & & & & & & \\
\hline Schmitz & 1998 Germany & Brownfield & Vegetation & Berlin & $\mathrm{Cfb}$ & $\begin{array}{l}\text { Former inner-German } \\
\text { border area }\end{array}$ & na & Past herbicide use & $\begin{array}{l}\text { Influence of surrounding gardens, areas } \\
\text { contribute to urban biodiversity }\end{array}$ \\
\hline Shaltout & 2002 Egypt & multi & Vegetation & multi & BWh & $\begin{array}{l}\text { Demolished houses, } \\
\text { abandoned fields, refuse } \\
\text { areas, railway, roads }\end{array}$ & na & $\begin{array}{l}\text { Fire, cutting, digging, } \\
\text { trampling, waste dump, } \\
\text { maintenance, pollution }\end{array}$ & $\begin{array}{l}\text { Urban vegetation favored disturbance, } \\
\text {, nutrient and water resources are abundant }\end{array}$ \\
\hline $\begin{array}{l}\text { Shushpannik } \\
\text { ova }\end{array}$ & 2001 Russia & multi & Vegetation & Syktyvkar & Dfc & Verges, embankments & na & $\begin{array}{l}\text { Disturbance by motor } \\
\text { vehicles }\end{array}$ & $\begin{array}{l}\text { Enrichment from adventitious species, but } \\
\text { species composition loss in technogenic } \\
\text { sites }\end{array}$ \\
\hline Small & $2003 \mathrm{UK}$ & Brownfield & $\begin{array}{l}\text { Carabid } \\
\text { beetles }\end{array}$ & Birmingham & $\mathrm{Cfb}$ & $\begin{array}{l}\text { Former factory, housing } \\
\text { an railway ground }\end{array}$ & 63 & & $\begin{array}{l}\text { Most species rich assemblages found on } \\
\text { early successional sites }\end{array}$ \\
\hline Small & $2006 \mathrm{UK}$ & Brownfield & Carabids & $\begin{array}{l}\text { West } \\
\text { Midlands }\end{array}$ & $\mathrm{Cfb}$ & Derelict land & 32 & & $\begin{array}{l}\text { Habitat quality (early successional sites } \\
\text { with diversity of seed producing plants) } \\
\text { important }\end{array}$ \\
\hline Smith-Adao & $\begin{array}{r}2007 \text { South } \\
\text { Africa }\end{array}$ & Waterside & Vegetation & $\begin{array}{l}\text { Somerset } \\
\text { West }\end{array}$ & $\mathrm{Csb}$ & $\begin{array}{l}\text { Riverbank (partly } \\
\text { modified) }\end{array}$ & na & Degradation & $\begin{array}{l}\text { Channel discharge changes and riparian } \\
\text { vegetation changes controlled channel } \\
\text { instability }\end{array}$ \\
\hline Strauss & 2006 Germany & Brownfield & $\begin{array}{l}\text { Leafhoppers, } \\
\text { grasshoppers }\end{array}$ & $\begin{array}{l}\text { Bremen, } \\
\text { Berlin }\end{array}$ & $\mathrm{Cfb}$ & Derelict sites & $146 / 130$ & $(\mathrm{LH}), 11 / 15(\mathrm{GH})$ & $\begin{array}{l}\text { Vegetation structure most important, } \\
\text { species prefer certain succession stages }\end{array}$ \\
\hline Stylinski & 1999 USA & Brownfield & Vegetation & San Diego & Bsk & $\begin{array}{l}\text { Formerly severely } \\
\text { disturbed sites (e.g. } \\
\text { military training ground) }\end{array}$ & 140 & & $\begin{array}{l}\text { Exotic species dominate, native species } \\
\text { cover low even after } 70 \text { years }\end{array}$ \\
\hline $\begin{array}{l}\text { Sudnik- } \\
\text { Wojcikowsk } \\
\text { a }\end{array}$ & 2005 Poland & multi & Vegetation & Warsaw & $\mathrm{Cfb}$ & $\begin{array}{l}\text { Tramlines and building } \\
\text { surface }\end{array}$ & 213,11 & Maintenance, herbicid & $\begin{array}{l}\text { Higher number of therophytes, many } \\
\text { (light) tree seedlings on building surface }\end{array}$ \\
\hline Tabata & 1978 Japan & Waterside & $\begin{array}{l}\text { Birds, ground- } \\
\text { beetles }\end{array}$ & -Tokyo & $\mathrm{Cfa}$ & $\begin{array}{l}\text { Highly modified river } \\
\text { bed and banks }\end{array}$ & 23,32 & $\begin{array}{l}\text { River modifications, } \\
\text { land use, water quality }\end{array}$ & $\begin{array}{l}\text { Complexity of land use and } \\
\text { environmental quality affects birds, } \\
\text { ground beetles and plants }\end{array}$ \\
\hline Tan & 2010 Singapore & Lot & Orthoptera & Singapore & Af & $\begin{array}{l}\text { Vacant lot vegetated } \\
\text { wasteland }\end{array}$ & 18 & $\begin{array}{l}\text { Disturbance, } \\
\text { development }\end{array}$ & $\begin{array}{l}\text { High diversity despite small area and high } \\
\text { disturbance }\end{array}$ \\
\hline Tommasi & 2004 Canada & multi & Bees & Vancouver & $\mathrm{Cfb}$ & $\begin{array}{l}\text { Powerline corridors, } \\
\text { road edges }\end{array}$ & na & & $\begin{array}{l}\text { Bloom and habitat heterogeneity are key } \\
\text { to urban area potential for bees }\end{array}$ \\
\hline Trammell & 2012 USA & Waterside & Birds & multi & Csb & Riparian patches & 59 & & $\begin{array}{l}\text { Urban structure (both land use and } \\
\text { vegetation) best described potential } \\
\text { habitat }\end{array}$ \\
\hline Uno & 2010 USA & Lot & Ants & multi & Dfa, D & $\begin{array}{l}\text { Former residential use } \\
\text { vacant lots }\end{array}$ & 20 & & $\begin{array}{l}\text { Exotic species abundance correlates with } \\
\text { ant species richness }\end{array}$ \\
\hline
\end{tabular}


First author Year Country IGS type Species groupStudy area Climate IGS description

\begin{tabular}{|c|c|c|c|c|c|c|c|c|}
\hline \multirow{2}{*}{\multicolumn{2}{|c|}{$\begin{array}{c}\text { Vakhlamova } 2014 \text { Kazakhsta multi } \\
n\end{array}$}} & \multicolumn{7}{|c|}{ number IGS } \\
\hline & & Vegetation & Pavlodar & Dfb & $\begin{array}{l}\text { Unmanaged land, } \\
\text { wasteland, industrial } \\
\text { land, landfills, eroded } \\
\text { patches }\end{array}$ & na & $\begin{array}{l}\text { Grazing, mowing, } \\
\text { trampling, waste } \\
\text { deposit, fire, industrial } \\
\text { contamination, traffic, }\end{array}$ & $\begin{array}{l}\text { Species diversity increased with distance } \\
\text { to city center, species richness at } \\
\text { unmanaged sites higher than at } \\
\text { ornamental sites, alien species lowest }\end{array}$ \\
\hline Venn & 2013 Finland & $\begin{array}{l}\text { Carabid } \\
\text { beetles }\end{array}$ & multi & Dfb & $\begin{array}{l}\text { Matrix grassland on } \\
\text { former military } \\
\text { fortifications }\end{array}$ & 34 & $\begin{array}{l}\text { Human population } \\
\text { density }\end{array}$ & $\begin{array}{l}\text { Urban dry meadows important habitats, } \\
\text { but matrix grassland least diverse, } \\
\text { important to avoid replacement with } \\
\text { asphalt }\end{array}$ \\
\hline Vincent & 1985 Canada & Vegetation & Montreal & $\mathrm{Dfb}$ & Vacant lots & 136 & & $\begin{array}{l}\text { Low diversity per site but high } \\
\text { discrimination among lots }\end{array}$ \\
\hline Wahlbrink & 1994 Germany Railway & Carabid beetl & Osnabrück & $\mathrm{Cfb}$ & Railway embankments & 52 & Herbicide & $\begin{array}{l}\text { Towards city center shannon diversity, } \\
\text { evenness and carabid body size decrease }\end{array}$ \\
\hline Weber & 2014 Germany Verge & $\begin{array}{l}\text { Herbaceous } \\
\text { plants }\end{array}$ & Berlin & $\mathrm{Cfb}$ & Roadside verges & & $\begin{array}{l}\text { Air pollution } \\
\text { (particulate matter) }\end{array}$ & $\begin{array}{l}\text { Not dedicated diversity survey, roadside } \\
\text { spont. Vegetation immobilizes significant } \\
\text { amount of air pollutants, increasing } \\
\text { biodiversity supports air filtration }\end{array}$ \\
\hline Westermann & 2011 Germany Railway & Vegetation & Berlin & $\mathrm{Cfb}$ & $\begin{array}{l}\text { Abandoned railway } \\
\text { areas }\end{array}$ & 210 & & $\begin{array}{l}\text { Environmental and landscape predictors } \\
\text { important, persistent seed bank } \\
\text { advantageous }\end{array}$ \\
\hline White & 2005 Australia Verge & Birds & Melbourne & $\mathrm{Cfb}$ & $\begin{array}{l}\text { Native, exotic and } \\
\text { recently developed } \\
\text { streetscapes }\end{array}$ & 44 & Planting choice & $\begin{array}{l}\text { Parks and native streetscapes have higher } \\
\text { species richness and abundance }\end{array}$ \\
\hline Whitmore & $\begin{array}{r}2002 \text { South } \\
\text { Africa } \\
\end{array}$ & Invertebrates & Durban & Cfa & Traffic islands & 232 & Design, management & $\begin{array}{l}\text { Enhanced islands (shrubs, herbs, trees) } \\
\text { support more species than mown islands }\end{array}$ \\
\hline Whitney & 1985 USA & Vegetation & Wooster & Dfa & $\begin{array}{l}\text { Powerline, vacant lots, } \\
\text { walls, railway, land fills }\end{array}$ & na & $\begin{array}{l}\text { Trampling, weeding, } \\
\text { herbicide }\end{array}$ & $\begin{array}{l}\text { Ruderal communities are American } \\
\text { analogues of common European urban } \\
\text { communities }\end{array}$ \\
\hline Winter & 2013 Germany multi & Vegetation & Bremen & $\mathrm{Cfb}$ & $\begin{array}{l}\text { Pavements, streets, } \\
\text { brownfields, railroad } \\
\text { tracks \& surroundings, } \\
\text { verges, construction } \\
\text { sites, vacant lots }\end{array}$ & na & $\begin{array}{l}\text { Development, mowing, } \\
\text { driving, walking, } \\
\text { dredging }\end{array}$ & $\begin{array}{l}\text { Harbor area is species-rich habitat, but } \\
\text { diversity is decreasing as result of } \\
\text { restructuring and restricted seed dispersal }\end{array}$ \\
\hline Wittig & 2010 multi & $\begin{array}{l}\text { Spont. } \\
\text { vegetation }\end{array}$ & multi & & Area around street trees & 194 & $\begin{array}{l}\text { Trampling, vegetation } \\
\text { clearing }\end{array}$ & $\begin{array}{l}\text { High similarity between sites in different } \\
\text { cities in Europe as well as the city in USA }\end{array}$ \\
\hline
\end{tabular}

\section{Species Human impact on Value and comments regarding IGS} number IGS

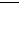


First author Year Country IGS type Species groupStudy area Climate IGS description

Species Human impact on Value and comments regarding IGS

\begin{tabular}{|c|c|c|c|c|c|c|c|c|c|}
\hline & & & & & & & \multicolumn{3}{|c|}{ number IGS } \\
\hline Wojcik & 2012 USA & Verge & Bees & multi & $\mathrm{Csb}$ & $\begin{array}{l}\text { Spontaneous vegetation } \\
\text { verges }\end{array}$ & na & & $\begin{array}{l}\text { Magnitude of floral resource and foraging } \\
\text { energetics factors important irrespective } \\
\text { of location }\end{array}$ \\
\hline Yamano & 2004 Japan & multi & Vegetation & Tsukuba & $\mathrm{Cfa}$ & $\begin{array}{l}\text { Vacant land, former } \\
\text { parking lot }\end{array}$ & na & & $\begin{array}{l}\text { Vacant lands contain more hybrid } \\
\text { (tetraploid) dandelions than natives }\end{array}$ \\
\hline Yamato & 2004 Japan & multi & Grass & multi & $\mathrm{Cfa}$ & $\begin{array}{l}\text { Construction sites, } \\
\text { expressway slopes, } \\
\text { airfields }\end{array}$ & & $\begin{array}{l}\text { Weeding, management, } \\
\text { cutting }\end{array}$ & $\begin{array}{l}\text { Management changes are leading to } \\
\text { change in plant associations }\end{array}$ \\
\hline Zapparoli & 1997 Italy & Brownfield & Centipedes & Rome & Csa & Urban wasteland & 20 & Fire, former land use & $\begin{array}{l}\text { Relatively high number of species, about } \\
57 \% \text { of whole Rome centipede fauna }\end{array}$ \\
\hline Zerbe & $\begin{array}{r}2004 \text { South } \\
\text { Korea } \\
\end{array}$ & multi & $\begin{array}{l}\text { Non-native } \\
\text { plants }\end{array}$ & Chonju & Dfa & $\begin{array}{l}\text { Railway, roadway, } \\
\text { fallow land }\end{array}$ & na & Disturbance & $\begin{array}{l}\text { Non-native species play a significant role } \\
\text { in enhancing urban area biodiversity }\end{array}$ \\
\hline Zhao & 2009 China & multi & Vegetation & Beijing & Dwa & $\begin{array}{l}\text { Greenspace in vacant } \\
\text { land without definite } \\
\text { land use }\end{array}$ & na & Land use & $\begin{array}{l}\text { Changes in plant species composition in } \\
\text { built-up areas, more than half non-native }\end{array}$ \\
\hline Zorenko & 2003 Latvia & multi & Mammal & Riga & Dfb & $\begin{array}{l}\text { Weeds/ruderal, highway } \\
\text { edges, river/lake banks }\end{array}$ & na & Anthropogenic load & $\begin{array}{l}\text { Species diversity increases towards city } \\
\text { periphery }\end{array}$ \\
\hline
\end{tabular}

